\title{
Detrital zircon records of the Paleo-Mesoproterozoic rift-sag Tamanduá Group in its type-section, Northern Quadrilátero Ferrífero, Minas Gerais, Brazil
}

\author{
Luiz Fernandes Dutra ${ }^{*}$ (D), Sérgio Patusco Dias $^{2}$ (D), Maximiliano Martins ${ }^{2}$ (D), \\ Cristiano Lana ${ }^{2}$ (D), Ana Carolina Batista ${ }^{2}$ (D), Tulio Delôgo Tavares² (D)
}

\begin{abstract}
The Quadrilátero Ferrifero metallogenetic province is located in the southernmost portion of the São Francisco craton, SE Brazil. The Tamanduá and Cambotas ridges stand out topographically in the northeastern portion of Quadrilátero Ferrífero and show NE-SW and N-S directions, respectively. Those ridges involve metasedimentary rocks of the Tamanduá Group bounded by a fault system. Due to stratigraphic and structural complexities, there is little consensus about the maximum sedimentation age and the stratigraphic position in which Tamanduá Group sediments were deposited. In this work, we took advantage of the excellent exposures in the Tamanduá and Cambotas ridges to present detailed stratigraphic observations combined with U-Pb zircon geochronological data from samples of different stratigraphic levels of Tamanduá Group. Furthermore, we provide U-Pb data from samples of the intrusive Pedra Formosa Suite that cut the whole Tamanduá sequence in the study area. Our observations showed that the Tamanduá Group represents a rift-sag basin-fill succession developed along the eastern border of the São Francisco paleoplate. The basal metaconglomerate and metasandstone package grades upward into marine metasandstone and phyllite. Detrital zircon obtained from the basal unit, Antônio dos Santos Formation, reveals maximum depositional ages between ca. 1981 and $1770 \mathrm{Ma}$. The upper succession, Cambotas Formation, shows a maximum depositional age from 1769 to 1740 Ma. The Pedra Formosa Suite shows zircons that crystallized at ca. $1740 \mathrm{Ma}$. The stratigraphic framework and the Orosirian-Statherian ages suggest a correlation with the first rifting event within the São Francisco paleoplate, the precursor of Paleo- to Mesoproterozoic Espinhaço basin.
\end{abstract}

KEYWORDS: Tamanduá Group; Espinhaço System; detrital zircons; São Francisco Craton; rift-sag sedimentation.

\section{INTRODUCTION}

In Proterozoic times, several sedimentary basins are registered in the interior and the boundaries of the Neoproterozoic São Francisco craton (SFC), southeastern Brazil (e.g., Alkmim and Martins-Neto 2012, Guadagnin and Chemale Jr. 2015). The intracratonic basins (Fig. 1) comprise several sedimentary sequences separated by unconformities as the main result of continuous and significant changing patterns of intraplate tectonic regimes (Alkmim and Martins-Neto 2012). Thus, when these unconformities are, to varying degrees, obliterated by tectonic inversion and metamorphism developed by the Orosirian and the late Neoproterozoic orogenies, the distinction between these basin cycles is compromised.

\section{Supplementary material \\ Supplementary data associated with this article can be found in the} online version: Supplementary data.

${ }^{1}$ Universidade de São Paulo - São Paulo (SP), Brazil. E-mail: luizdutra@usp.br ${ }^{2}$ Universidade Federal de Ouro Preto - Ouro Preto (MG), Brazil. E-mails: sergiopatuscodias@yahoo.com.br, maximilianomartins@ yahoo.com.br, cristianodeclana@gmail.com, batista.ana22@gmail.com, tuliodelogo@yahoo.com.br

${ }^{*}$ Corresponding author.
The Tamanduá and Cambotas ridges (Fig. 2) materialize the physical connection between the Gandarela syncline, a sub-regional NE-SW structure related to the Archean-Paleoproterozoic Quadrilátero Ferrífero metallogenetic province (QF, Iron Quadrangle), and the N-S PaleoMesoproterozoic Southern Espinhaço ridge. The Tamanduá and Cambotas ridges (Fig. 2) are the locus typicus of the metasedimentary Tamanduá Group described by Simmons and Maxwell (1961), considered as the fundamental unit in the northern QF to understand the temporal distribution of QF and Southern Espinhaço units, as pioneering observed by Harder and Chamberlin (1915) and Guimarães (1931), and later reinforced by Simmons and Maxwell (1961), Hirson (1967), Simmons (1968), Moore (1969), and Dorr II (1969). The temporal and stratigraphic positioning of the Tamanduá Group is speculative due to the absence of non-tectonic contacts between the metasedimentary sequences in the Gandarela, Tamanduá, and Cambotas ridges. Four hypotheses constitute the most disseminated stratigraphic proposals to the Tamanduá Group (Tab. 1). The early proposal points to the correlation of the Tamanduá Group with the QF units, i.e., Archean Rio das Velhas greenstone belt or NeoarcheanRyacian Minas Supergroup. On the other hand, since the late 1970s, several authors have proposed the association of the Tamanduá Group with the Espinhaço Supergroup. Castro and Pedrosa (1982) suggested a hybrid hypothesis, correlating 
the Tamanduá Group as a "connection unit" between the Espinhaço and Minas supergroups.

As a rule, the use of detailed field surveys in critical areas associated with $\mathrm{U}-\mathrm{Pb}$ geochronology in detrital zircons grains has revealed one of the most powerful tools to determine the crustal evolution of ancient sedimentary basins (Kleinspehn and Paola 1988). On the last decades, several authors (e.g., Machado et al. 1996, Santos et al. 2006, Chemale Jr. et al. 2012, Farina et al. 2016, Moreira et al. 2016) presented studies in the intracratonic basins of the QF and Southern Espinhaço

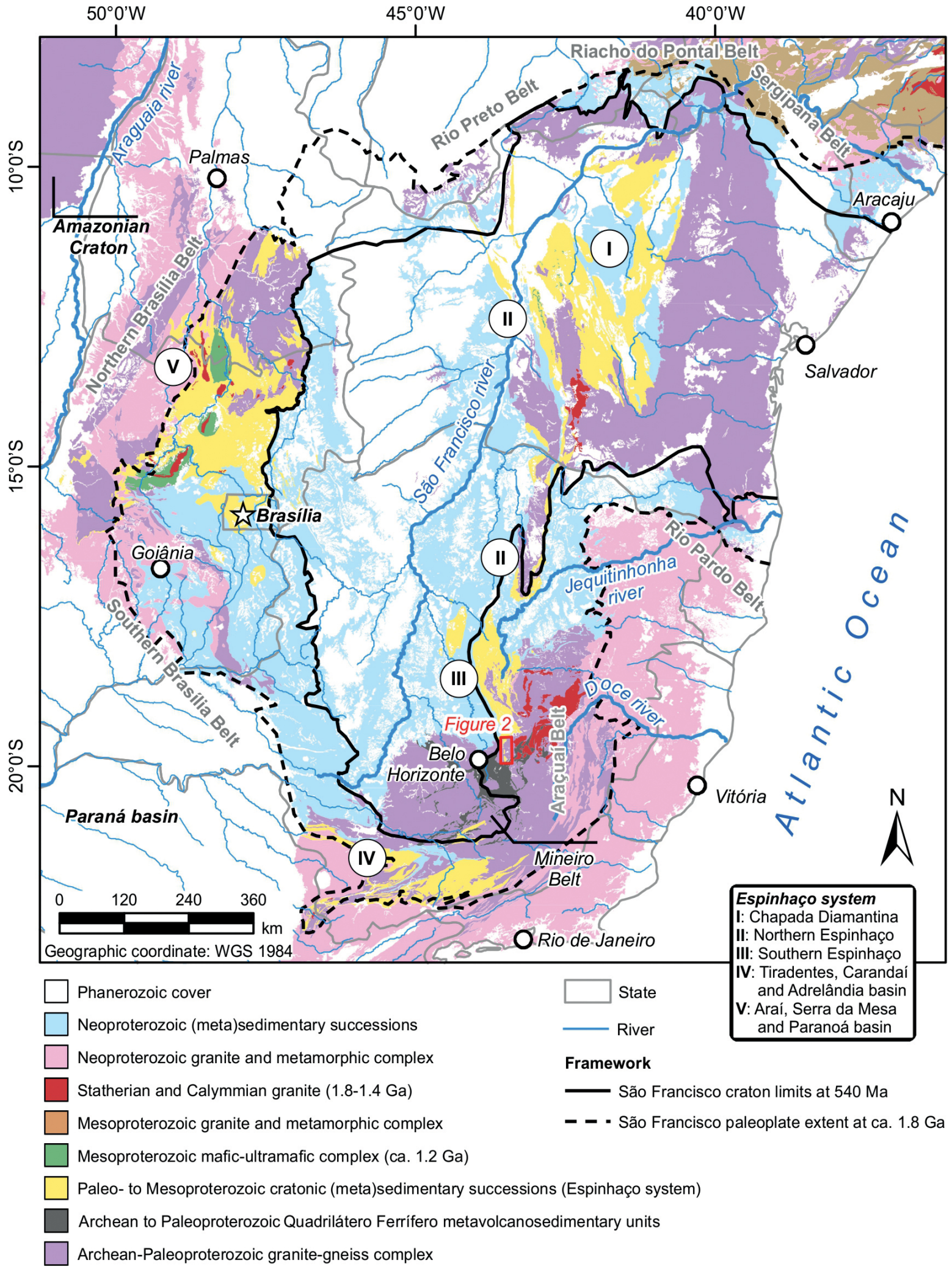

Figure 1. Geological map of the main intracontinental basins of the São Francisco craton (base on Guadagnin and Chemale Jr. 2015). The black lines indicate the most accepted extension of the craton after ca. $540 \mathrm{Ma}$ and the continental paleocontinent one at ca. $1.8 \mathrm{Ga}$ (modified as proposed by Guimarães et al. 2014). The name of the Neoproterozoic belt is given in gray. This map was generated from the Geological Survey of Brazil (Companhia de Pesquisa de Recursos Minerais - CPRM) regional mapping shapefiles (CPRM 2018). 
Supergroup, highlighting its tectonics setting of the source area, depositional age, and evolution through time. The rocks of Caraça, Batatal, Ouro Branco, and Cambotas-Tamanduá ridges (Fig. 3) present lithostratigraphic similarities that led to the interpretation of a single unit (i.e., Maxwell 1972, Dorr
II 1969, Angeli 2016, Romano et al. 2017). Nonetheless, geochronological studies and lithostratigraphic research indicate that the metasedimentary rocks belong to the Caraça, the Itacolomi or the Tamanduá Group (Almeida et al. 2005, Alkmim et al. 2014, Nunes 2016, Dutra 2017).

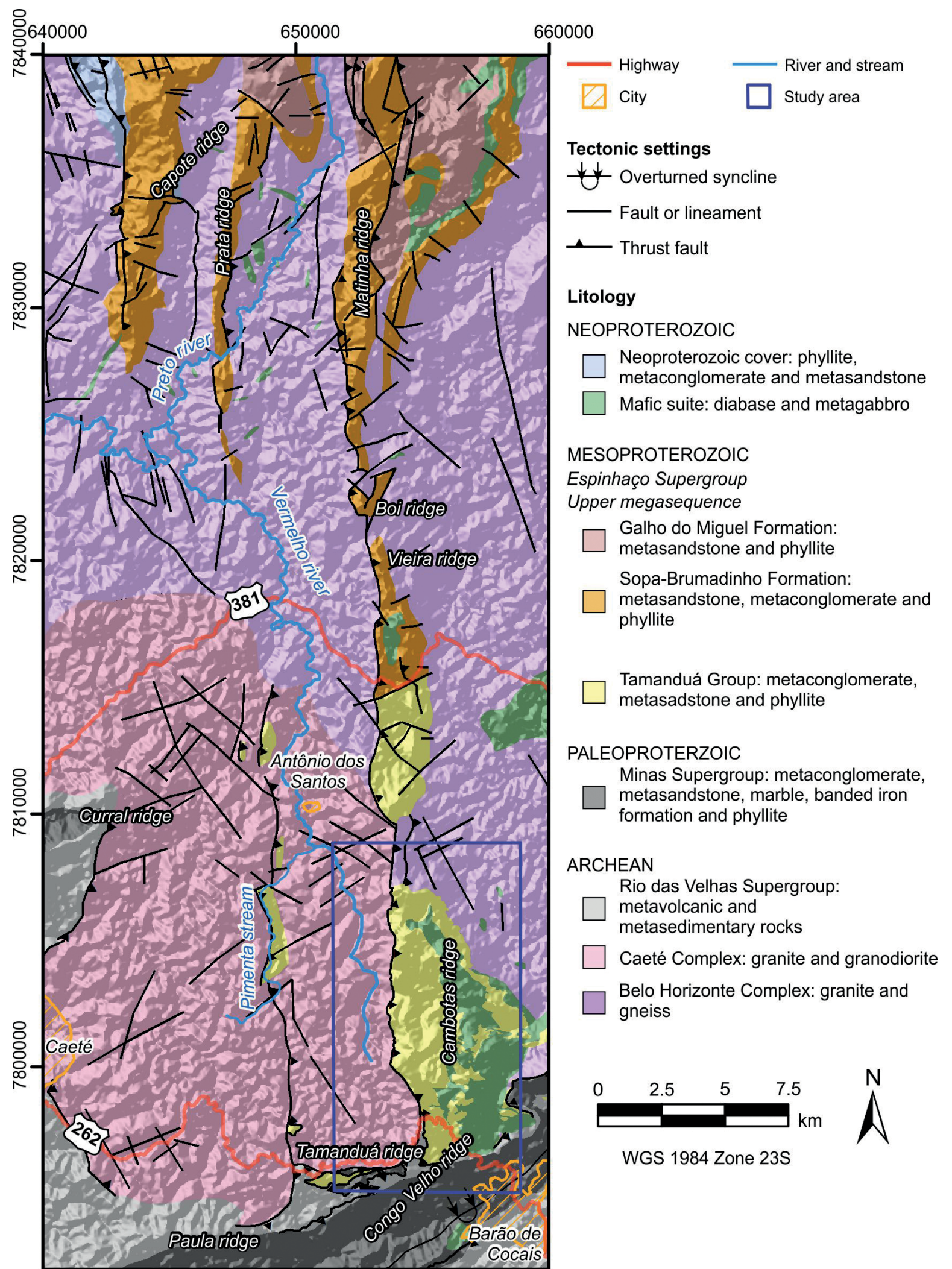

Figure 2. Composition of shaded relief and geological map of NE Quadrilátero Ferrífero and Southern Espinhaço ridge (based on Lobato et al.2005, Saraiva 2012, Katahira 2013, Almeida-Filho et al.2015, Gomes 2017). Hydrography data from the Brazilian Institute of Geography and Statistics (Instituto Brasileiro de Geografia e Estatística - IBGE 2017). 
The previous $\mathrm{U}-\mathrm{Pb}$ dating of detrital zircon ages of the Tamanduá Group provides inaccurate maximum depositional age (2258 $\pm 71 \mathrm{Ma}$, Machado et al. 1996), due to the low amount of grains analyzed, samples, and minimum concordance (70\%). In order to evaluate sedimentary provenance, maximum/minimum depositional ages, and stratigraphic correlations, we combined stratigraphic observations and $\mathrm{U}-\mathrm{Pb}$ analysis from nine samples of units of the Tamanduá Group and mafic suite in the Tamanduá and Cambotas ridges.

\section{REGIONAL BACKGROUND}

The SFC comprises Archaean nuclei, Archean-Proterozoic metavolcanic-sedimentary sequences, and Paleoproterozoic arc-related granitoids that host several sedimentary basins from the Proterozoic to Phanerozoic and are surrounded by Neoproterozoic orogenic belts (Fig. 1) (Almeida 1977, Alkmim and Martins-Neto 2012).

The Archaean nuclei outcrop in the southern and northeastern portion of the SFC and encompass a mosaic of individual blocks bounded by Paleoproterozoic orogenic domains (Teixeira et al. 2017).
The southern exposure is represented by QF mining district and adjacent metamorphic complexes and greenstone belts (Teixeira et al.2017). In the QF, the Archean kernels are formed by domal igneous-metamorphic complexes encircled by the Rio das Velhas greenstone belt (i.e., dome-and-keel province; Cutts et al 2019) and partially covered by the Paleoproterozoic Minas basin (Fig. 3).

Granite-gneiss complexes are continental blocks and juvenile arcs whose agglutination dates back to Paleo- to Neoarchean tectonomagmatic events (Romano et al. 2012, Lana et al. 2013). The first stage of emplacement dates back to ca. 3200 Ma (Santa Bárbara event) with tonalite-trondhjemite-granodiorite that served as the main kernels for crustal growth in $2900 \mathrm{Ma}$ (Lana et al. 2013). The second stage, Rio das Velhas I event at 2920-2850 Ma, can be correlated to the development of the continental lithosphere in the southern portion of the SFC. The Rio das Velhas II event (2780-2730 Ma) is accompanied by high-grade metamorphism (Farina et al. 2016) and deposition of volcanic and mafic-ultramafic associations (Nova Lima Group) to turbidite deposits (Maquiné Group) of the Rio das Velhas Supergroup (Lana et al. 2013, Moreira et al. 2016, Martínez Dopico et al. 2017). The stabilization of Southern

Table 1. The hypothesis for the stratigraphic position of the Tamanduá Group.

\begin{tabular}{|c|c|c|c|c|}
\hline References & $\begin{array}{l}\text { Rio das Velhas } \\
\text { Supergroup }\end{array}$ & $\begin{array}{c}\text { Minas } \\
\text { Supergroup }\end{array}$ & $\begin{array}{l}\text { Espinhaço } \\
\text { Supergroup }\end{array}$ & $\begin{array}{c}\text { Minas and } \\
\text { Espinhaço } \\
\text { supergroups }\end{array}$ \\
\hline \multicolumn{5}{|l|}{ Simmons and Maxwell (1961) } \\
\hline \multicolumn{5}{|l|}{ Hirson (1967) } \\
\hline \multicolumn{5}{|l|}{ Simmons (1968) } \\
\hline \multicolumn{5}{|l|}{ Dorr II (1969) } \\
\hline \multicolumn{5}{|l|}{ Moore (1969) } \\
\hline \multicolumn{5}{|l|}{ Herz (1970) } \\
\hline \multicolumn{5}{|l|}{ Schöll $(1972)^{1}$} \\
\hline \multicolumn{5}{|l|}{ Maxwell (1972) } \\
\hline \multicolumn{5}{|l|}{ Amaral et al. (1976) } \\
\hline \multicolumn{5}{|l|}{ Schorscher and Guimarães $(1976)^{2}$} \\
\hline \multicolumn{5}{|l|}{ Besang et al. (1977) } \\
\hline \multicolumn{5}{|l|}{ Sperber (1977) } \\
\hline \multicolumn{5}{|l|}{ Schorscher $(1978,1979 a, 1979 b, 1980)$} \\
\hline \multicolumn{5}{|l|}{ Herz $(1978)$} \\
\hline \multicolumn{5}{|l|}{ Castro and Pedrosa (1982) } \\
\hline \multicolumn{5}{|l|}{ Ladeira (1982) } \\
\hline \multicolumn{5}{|l|}{ Marshak and Alkmim (1989) } \\
\hline \multicolumn{5}{|l|}{ Crocco-Rodrigues (1991) } \\
\hline \multicolumn{5}{|l|}{ Freitas et al. (1991) } \\
\hline \multicolumn{5}{|l|}{ Alkmim and Marshak (1998) } \\
\hline \multicolumn{5}{|l|}{ CPRM (2003) } \\
\hline \multicolumn{5}{|l|}{ Lobato et al. (2005) } \\
\hline CPRM (2014) & & & & \\
\hline
\end{tabular}

${ }^{1}$ The rocks of the Cambotas ridge are part of the "Espinhaço zone" of the Minas Supergroup; ${ }^{2}$ they propose a chrono-correlation between the Minas and Espinhaço supergroups. 
SFC is marked by potassium-rich granite in the Mamona event (2750-2700 and 2620-2580 Ma, Mamona I and Mamona II, respectively) (Farina et al.2016, Martínez Dopico et al.2017).

The Minas Supergroup unconformably overlies the Rio das Velhas greenstone belt and the granite-gneiss complexes (Fig. 3). The Minas basin records stages of a rift for marine sedimentation (Caraça and Itabira Group), passive margin (Piracicaba Group), and foreland basin (Sabará Group) (Dorr II 1969, Alkmim and Martins-Neto 2012). The Caraça Group comprises alluvial metasandstone and metaconglomerate (Moeda Formation) that grade into marine deposits of the Batatal Formation. The Itabira Group comprises metamorphized Lake Superior-type banded iron formation (Cauê Formation) and carbonates (Gandarela Formation). The marine and deltaic sequence of Piracicaba Group overlie the Gandarela Formation through an erosional surface (Dorr II 1969). The basal unit, Cercadinho Formation, comprises Fe-rich metasandstone, phyllite and metaconglomerate. The Fecho do Funil and Taboões formations are made up

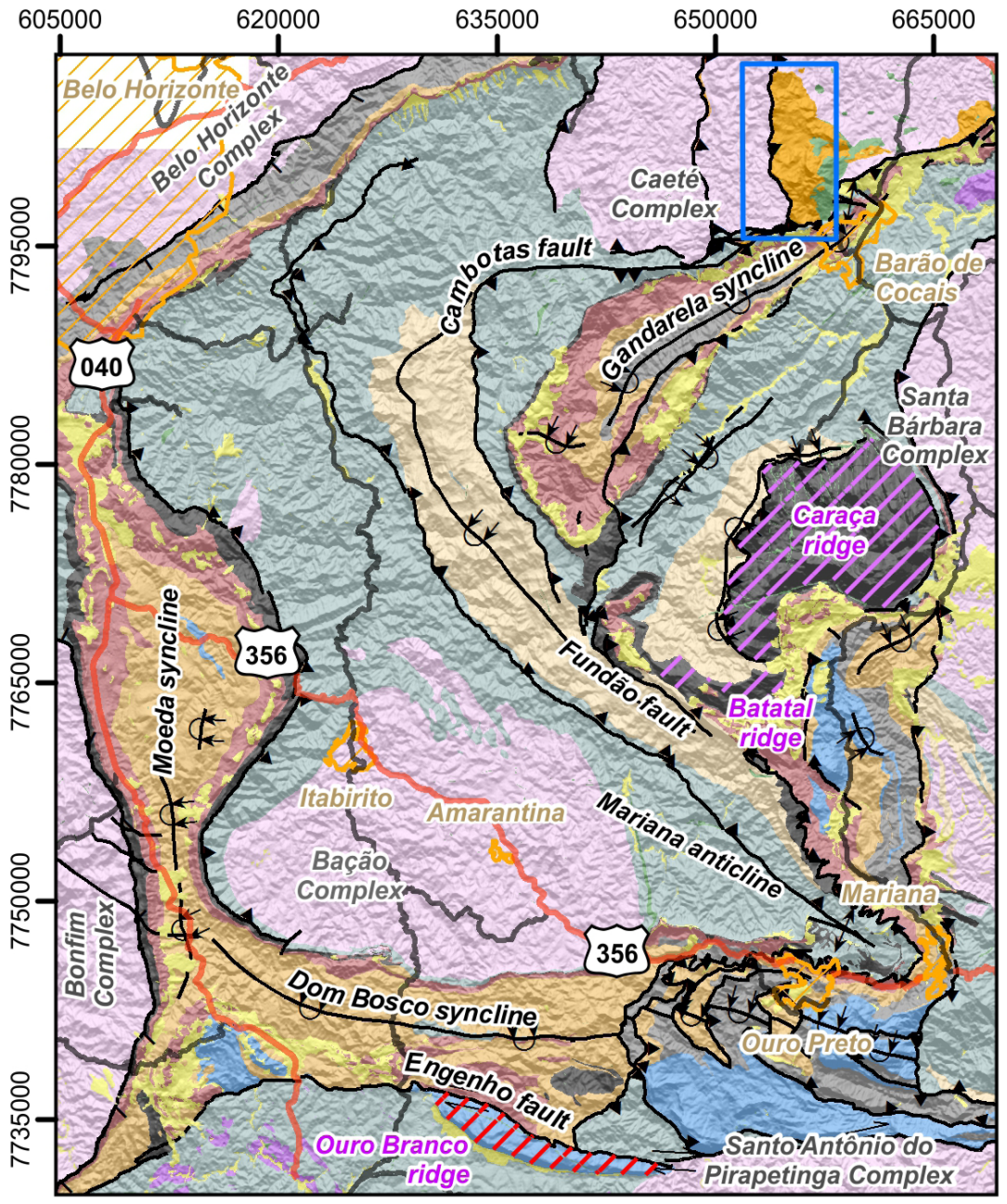

Studied area (Fig. 6)

City

- Federal highway
Tamanduá Group according to literature 8 Ouro Branco ridge

Proposed correlation: Dorr II (1969)

Revised lithology:

Almeida et al. (2005): Itacolomi Group Alkmim et al. (2014): Itacolomi Group based on $\mathrm{U}-\mathrm{Pb}$ geochronology

\section{Caraça-Batatal ridge}

Proposed correlation: Maxwell (1972), Dorr II (1969), Angeli (2016) and Romano et al. (2017)

Revised lithology: CPRM (2003): Caraça Group Nunes (2016): Caraça Group based on $\mathrm{U}-\mathrm{Pb}$ geochronology

Tamanduá-Cambotas ridge

Proposed correlation: Simmons (1968), Dorr II (1969) and Moore (1969)

Revised lithology:

Crocco-Rodrigues (1991): Tamanduá Group CPRM (2003): Conselheiro Mata Group (Espinhaço Supergroup)

Gomes (2017): Tamanduá Group,

Dutra (2017):Tamanduá Group based on $\mathrm{U}-\mathrm{Pb}$ geochronology
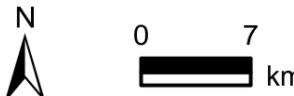

WGS 1984

Zone $23 S$

State highway

\section{Lithostratigraphy}

Cenozoic cover

Proterozoic metamafic rock

Neoarchean and Rhyacian granitoid rock

Tamanduá Group: metasandstone and metaconglomerate

Paleoproterozoic

Rhyacian

Itacolomi Group: metasandstone and metaconglomerate

MINAS SUPERGROUP

Sabará Group: metadiamictite, metaconglomerate,

metasandstone and metasiltstone
Piracicaba Group: metasandstone, metaconglomerate, metapelite and marble Siderian

Itabira Group: itabirite and marble

Archean

Neoarchean

Caraça Group: metaconglomerate, metasandstone and metapelite

RIO DAS VELHAS SUPERGROUP

$\square$ Maquiné Group: metaconglomerate

and metasandstone

Nova Lima Group: metasandstone

metapelite, metabasalt and metakomatiite

Paleo- to Neoarchean

Granite-gneiss complex
Tectonic settings

$\stackrel{\longleftarrow}{\longleftarrow}$ Shear fault $\uparrow$ Anticline fold $\downarrow \downarrow$ Overturned $\longrightarrow$ Fault

$\stackrel{\downarrow}{\downarrow}$ Syncline fold

$\downarrow \downarrow$ Overturned

Normal fault

- Thrust fault

Source: generated from the Lobato et al.s (2005) regional mapping shapefiles.

Figure 3. Geological map of the central portion of Quadrilátero Ferrífero and the occurrence of Tamanduá Group based on literature. 
of phyllite, dolomitic marble and orthometasandstone. The top unit, Barreiro Formation comprises metasandstone and graphitic phyllite. The Sabará Group, top unit of Minas Supergroup, is separated from the previous sequence by regional unconformities. This group is made up of metadiamictite, metaconglomerate, metasandstone and metasiltstone (Dorr II 1969, Reis et al. 2002). The Itacolomi Group is restricted in the southeast QF (Fig.3).It comprises an alluvial sequence with marine transitions (Alkmim 1987) and lies the Minas Supergroup unconformably.

Mafic suites are very common in the QF, especially in the Caraça and Cambotas ridges (Fig. 3). Dykes show different trends and ages. Silva et al. (1995) reported a baddeleyite $\mathrm{U}$-Pb upper intercept age of $1714 \pm 5 \mathrm{Ma}$ for Ibirité gabbro, one of the mafic dike swarms in the QF that cuts the Minas Supergroup. Additionally, Cederberg et al. (2016) recognized three NW-SE trending dike generations that intrude the granitoid complexes and Minas Supergroup in the western QF, dated at 1798-1793, 1717-1703, and $706 \pm 36 \mathrm{Ma}$.

The SFC Paleo- to Mesoproterozoic cover is related to the Espinhaço system and exposed by several inner intracratonic basins and in their borders (Fig. 1). Those units present lithological and stratigraphic arrangement similarities (Brito Neves et al. 1995, Guadagnin and Chemale Jr. 2015). In general, those basins encompass continental sediments in a rift-sag environment, in a polycyclic and poly-historic evolution, associated with mafic and/or felsic alkaline magmatism between 1.8 and $1.68 \mathrm{Ga}$ (Dussin and Dussin 1995, Danderfer et al. 2009, Danderfer Filho et al. 2015, Guadagnin and Chemale Jr. 2015). The opening of the Espinhaço basin is related to the crustal stretching in the aftermath of Minas accretionary orogeny (Machado and Abreu-Bentivi 1989). The crustal stretching may be the result of far-field stress (Danderfer Filho et al. 2015) or mantle plumes (Rosière et al. 2019). The Espinhaço basin fill-succession comprises three tectonostratigraphic megasequences, Lower Espinhaço (1.80-1.68 Ga), Middle Espinhaço (1.60-1.38 Ga), and Upper Espinhaço (1.2-0.9 Ga), which represent stages of the rift to sag basin (Chemale Jr. et al.2012). The minimum age of Espinhaço basin is defined from the mafic intrusive dykes swarms dated 964-957 Ma (de Castro et al. 2019, Souza et al. 2019).

The structural framework of the northeast portion of the QF is the result of at least two deformational events, the first in the Rhyacian-Orosirian period (Minas accretionary orogeny) and the second in the Late Neoproterozoic (Alkmim and Marshak 1998, Endo and Machado 2002). Several structures are coeval with Minas accretionary orogeny that generated regional folds, such as Gandarela syncline, overprinted by Neoproterozoic fault systems, i.e., Cambotas-Fundão fault system (Alkmim and Marshak 1998) and Córrego do Garimpo thrust belt (Crocco-Rodrigues et al. 1989).

\section{Lithostratigraphy of Tamanduá and Cambotas ridges}

The Tamanduá and Cambotas ridges are surrounded by Archean granitoid rocks and the Gandarela syncline (Figs. 2 and 3). The Archean complexes are represented by the gneiss, migmatite, and granitoid (Brandalise and Heineck 1999) of the Caeté and Belo Horizonte complexes. Meanwhile, the Gandarela syncline gathers the rocks of the Nova Lima Group, Minas Supergroup, and Tamanduá Group in a NW-tectonic vergence, ENE-WSW axial trace, and inverted south limb.

The Nova Lima Group encompasses phyllite, chlorite, and sericite-quartz schist in the northern limb of the Gandarela syncline (Fig. 3). The Caraça Group occurs in discontinuous bodies near the Tamanduá ridge, which encompasses finegrained sericite metasandstone (Moeda Formation) covered by sericite phyllite (Batatal Formation). The Itabira Group comprises itabirite (metamorphized banded iron formation, Cauê Formation) and dolomite (Gandarela Formation). The Tamanduá Group is represented by metasandstone and metaconglomerate in the Tamanduá ridge bounded by subsidiary thrust faults of the Cambotas fault.

The Fundão-Cambotas fault system presents the cartographic trace similar to that of the syncline and projects the Nova Lima Group on top of the Minas Supergroup (Fundão fault) and this unit on the Tamanduá Group (Simmons 1968, Moore 1969). This fault system and an erosive and angular surface separate the Itabira Group from the Nova Lima Group and the overlying Cercadinho Formation (Piracicaba Group). The fine- to medium-grained metasandstone interbedded with phyllite of Cercadinho Formation is the only unit of Piracicaba Group that outcrops in the NE QF. The Sabará Group is made up of phyllite and, locally, fine-grained metasandstone (Simmons 1968, Moore 1969, Alkmim and Marshak 1998, Dutra 2017, Dutra et al. 2019).

The Córrego do Garimpo thrust belt is interpreted as imbricated tectonic fans and encompasses the Córrego do Garimpo (the west limb of Cambotas ridge) and Montalvão faults (inner Caeté complex). This thrust belt shows an N-S direction and W-vergence (Crocco-Rodrigues 1991).

\section{Stratigraphy of Tamanduá Group in its type-section}

The lithostratigraphic description of the Tamanduá Group in its type-section was based on 1:10,000 geological mapping made by Gomes (2017), comprising the "Cambotas Quartzite" of Upper Unit of Simmons and Maxwell (1961) and the reviews proposed by Simmons (1968), Moore (1969), and Crocco-Rodrigues (1991).

The Tamanduá Group encompasses polymictic metaconglomerate and metasandstone that grades upward and laterally into metasandstone interbedded with metarkose and, as upper rocks, phyllite and sericite metasandstone. This sequence is divided into Antônio dos Santos and Cambotas formations, where, from the base to the top, the first one comprises the Córrego do Garimpo and Serra do Garimpo members and the second one, Rio Vermelho, São Miguel, and Ribeirão Cocais members (Gomes 2017) (Fig. 4).

The Córrego do Garimpo member (Figs. 5A and B) is made up of matrix- and clast-supported metaconglomerate with pebbles of quartz, banded iron-formation, granite-gneiss and micaceous, pure and ferruginous metasandstones. The pebble diameter ranges from 1 to $30 \mathrm{~cm}$. The pebble tends to well-rounded 
forms, but the banded iron-formation one is oblate in the less deformed portion of this rock. The predominant pebbles comprise metasandstone and banded iron-formation embedded in a matrix of very fine- to very coarse-grained quartz grains with a high level of micas. Occurrences of medium- to coarsegrained sericite metasandstone with sub-rounded to sub-angular grains are subordinate within the metaconglomerate. The Serra do Garimpo member comprises fine- to medium-grained metasandstone with high angle cross-stratification, sub-rounded and well-sorted quartz grain (Figs. 5C and 5D).

The Cambotas Formation encompasses metasandstone and constitutes the most significant portion of the Cambotas-Tamanduá ridge. The Rio Vermelho member comprises fine-to coarse-grained metasandstone with metarkose bed and tabular stratification (Fig. 5E). Lowlands, plains, and meadows characterize its geomorphological domain in the Cambotas ridge. The São Miguel

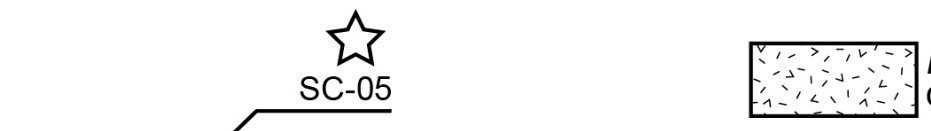

Pedra Formosa Suite diabase and metagabbro

1570

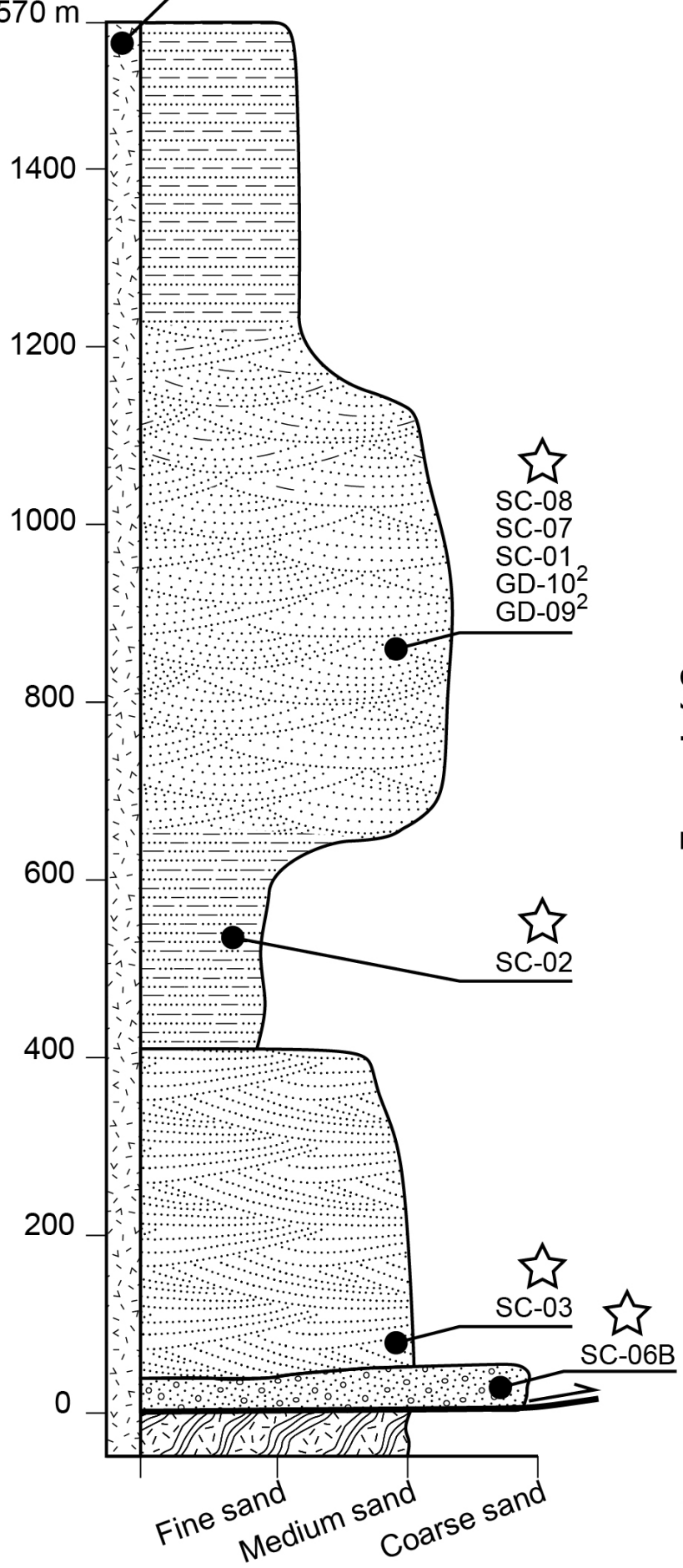

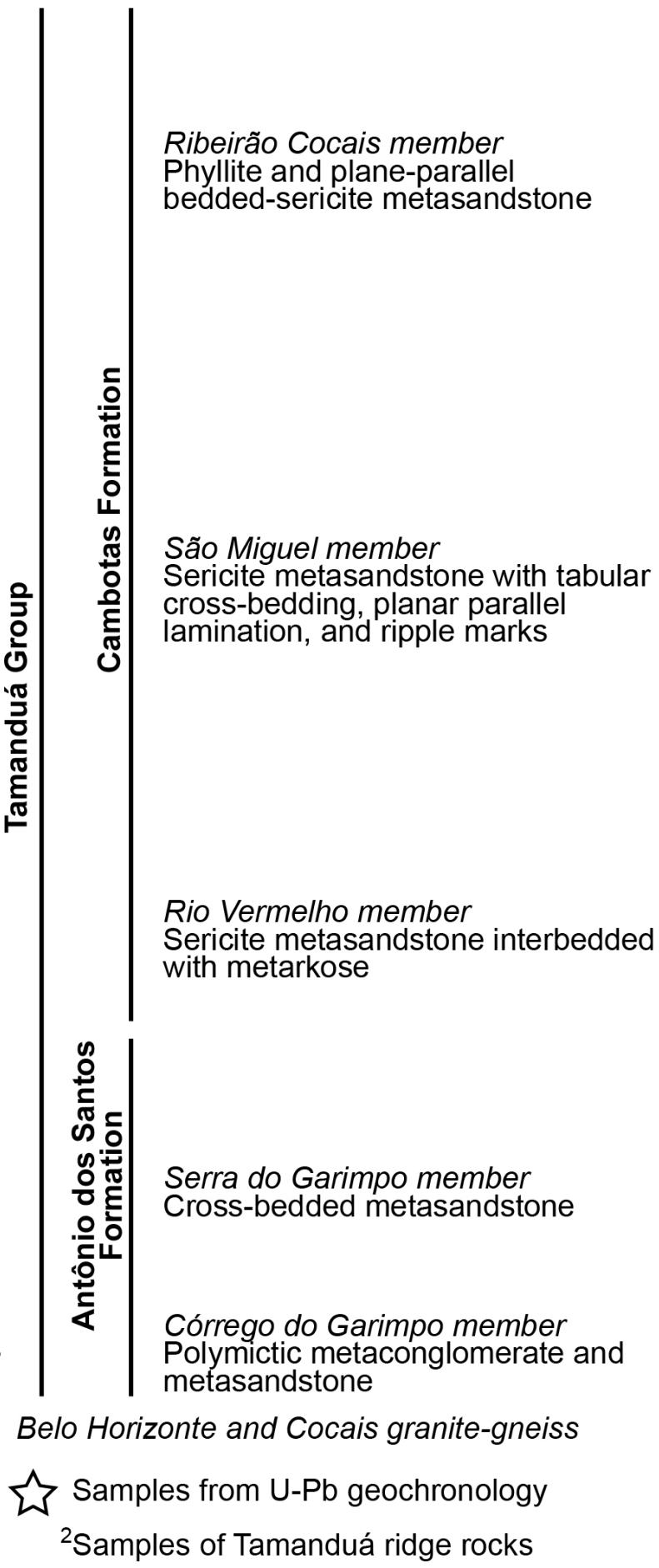

Figure 4. Stratigraphic column of Cambotas-Tamanduá range and the adjacent area proposed by Gomes (2017) (symbology by U.S. Geological Survey 2006). 

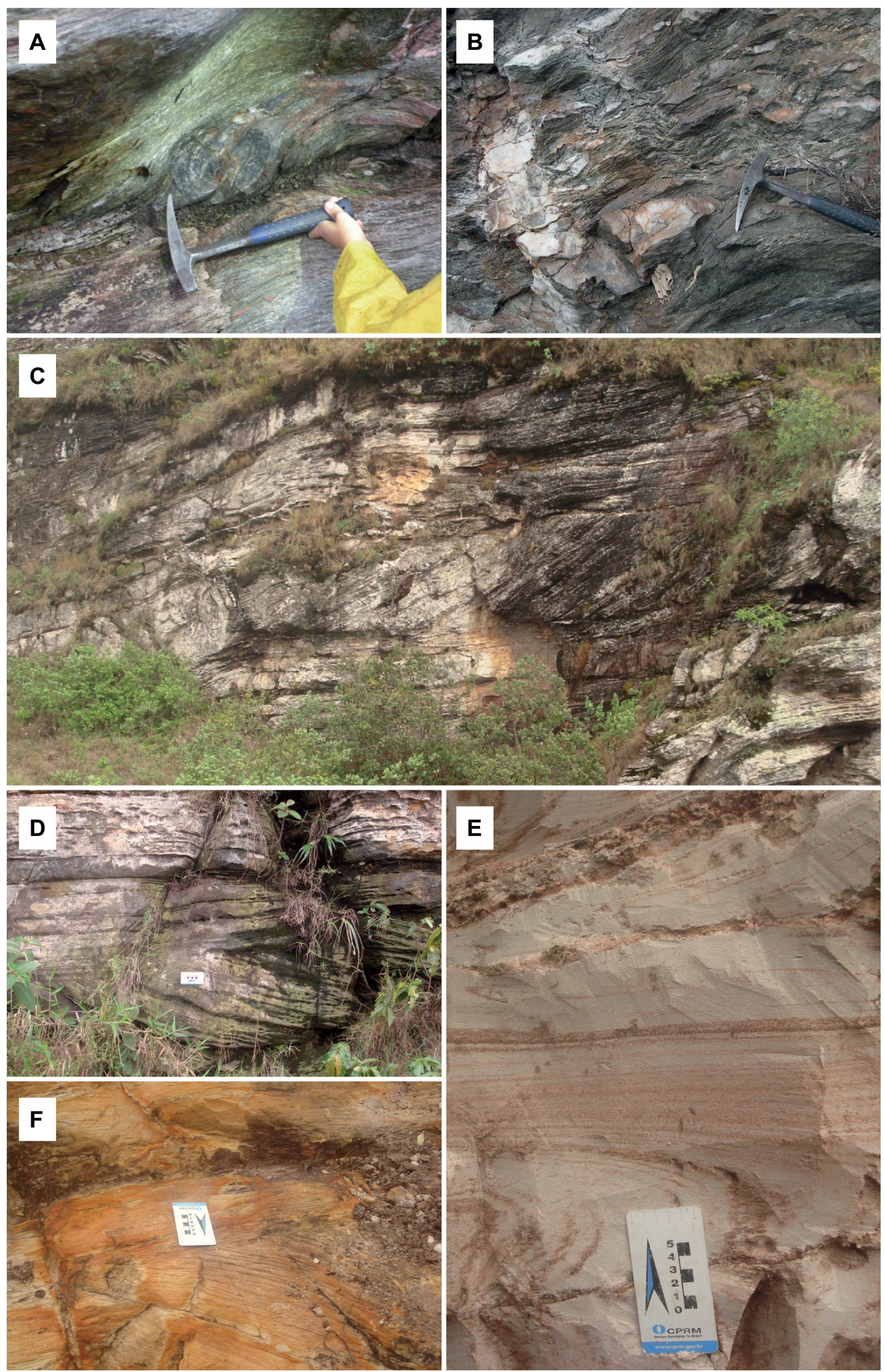

Figure 5. (A) and (B) Deformed matrix-supported metaconglomerate of Córrego do Garimpo member (Antônio dos Santos Formation) with well foliated matrix. (C) and (D) High-angle cross-stratified metasandstone of Serra do Garimpo member (Antônio dos Santos Formation). (E) Metasandstone with kaolin lenses of Rio Vermelho member (Cambotas Formation). (F) Cross-stratified metasandstone of São Miguel member (Cambotas Formation). 
member (Fig. 5F) comprises fine- to coarse-grained metasandstone that ranges from orthometasandstone to mica metasandstone and large-scale cross-stratification, tabular cross-bedding, planar parallel lamination, and ripple marks. Generally, São Miguel metasandstone exhibits yellowish to brownish or pink color. The Ribeirão Cocais member is made up of very fine- to fine-grained metasandstone with planar parallel stratification and low-angle cross laminae, locally, occurs hummocky.

The contacts of the Tamanduá Group are marked by unconformity or faults (Simmons and Maxwell 1961, Simmons 1968, Moore 1969, Crocco-Rodrigues 1991) with the units of Rio das Velhas and Minas Supergroups and even with the granite-gneiss complexes (Figs. 2 and 3 ). The nature of contact between Antônio dos Santos and Cambotas formations is abrupt and tectonized (Gomes 2017).

\section{Pedra Formasa Suite}

The Pedra Formosa Suite comprises dykes, stocks, and sills that crosscut the Tamanduá Group. The diabase is black to bluish-gray and exhibits aphanitic texture. The metagabbro, a fine- to coarse-grained rock, is dark green (Crocco-Rodrigues 1991, Almeida-Filho et al. 2015, Gomes 2017). The intense weathering led to the development of thick cover of eutroferric dark-brownish and red latosol; thus, fresh outcrops are uncommon (Figure 6).

\section{U-Pb GEOCHRONOLOGY}

\section{Samples and $\mathrm{U}-\mathrm{Pb}$ dating}

Samples were collected across the Cambotas ridge (Tab. 2, Fig. 7) from Antônio dos Santos Formation and Rio Vermelho and São Miguel members of Cambotas Formation. The two samples of the Tamanduá ridge were analyzed by Dutra (2017).

About $15 \mathrm{~kg}$ of rocks for each sample (nine) were collected for $\mathrm{U}-\mathrm{Pb}$ analyses of zircon grains and the entire procedure was conducted in the Departamento de Geologia of the Universidade Federal de Ouro Preto (DEGEO/UFOP). The samples were crushed and pulverized with a jaw crusher and grinder. Heavy minerals were concentrated by manual panning and, subsequently, by magnetic methods. Non-magmatic zircons were handpicked, and the grains were mounted in 25-mm-diameter epoxy mounts (SpeciFix). The preparation process was carried out in the Laboratory of Preparation of Geochronological Samples (LOPAG). After polishing, the zircon grains were imagined by Scanning Electron Microscope using a JEOL 6510 equipped with a Centaurus cathodoluminescence (CL) detector at the Microanalysis Laboratory (MICROLAB)

Zircon U-Pb isotopes were analyzed in a ThermoScientific Element 2 sector field (SF) ICP-MS coupled to a CETAC

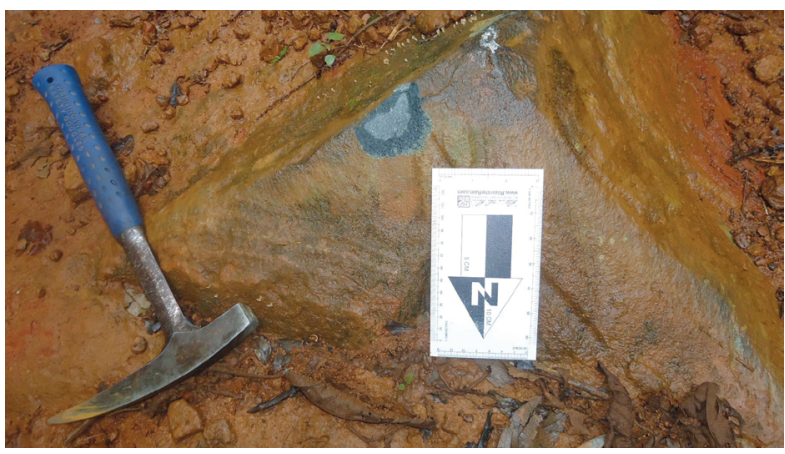

Figure 6. Typical outcrop of Pedra Formosa Suite (courtesy of Mayko Neves).

Table 2. Summary of the geochronological samples of Tamanduá Group.

\begin{tabular}{|c|c|c|c|c|}
\hline Samples & $\begin{array}{c}\text { Coordinates } \\
(\text { WGS } 198423 S)\end{array}$ & $\begin{array}{c}\text { Analyzed grains } \\
\text { (concordant age zircon) }\end{array}$ & Unit & Description \\
\hline SC-05 & $657619 / 7798343$ & $59(27)$ & Pedra Formosa Suite & Metagabbro \\
\hline SC-08 & $654482 / 7801293$ & $120(102)$ & & $\begin{array}{l}\text { Very fine- to fine-grained } \\
\text { sericite-metasandstone }\end{array}$ \\
\hline SC-07 & $654040 / 7800963$ & $118(42)$ & São Miguel member & $\begin{array}{l}\text { Very fine- to fine-grained } \\
\text { sericite-metasandstone with dispersed } \\
\text { metasandstone and quartz clasts }\end{array}$ \\
\hline SC-01 & $654237 / 7804593$ & $119(103)$ & (Cambotas Formation) & $\begin{array}{l}\text { Moderated sorted fine- to } \\
\text { medium-grained metasandstone with } \\
\text { sub-angular to sub-rounded grains }\end{array}$ \\
\hline GD- $10^{1}$ & $653032 / 7796006$ & $60(50)$ & & \multirow{2}{*}{ Fine- to medium-grained metasandstone } \\
\hline GD-09 1 & $652277 / 7795656$ & $89(87)$ & & \\
\hline SC-02 & $654163 / 7805797$ & $119(53)$ & $\begin{array}{l}\text { São Miguel member } \\
\text { (Cambotas Formation) }\end{array}$ & Fine grained sericite-metasandstone \\
\hline SC-03 & $654010 / 7807059$ & $116(95)$ & $\begin{array}{l}\text { The base of Serra do } \\
\text { Garimpo member (Antônio } \\
\text { dos Santos Formation) }\end{array}$ & $\begin{array}{l}\text { Well sorted fine- to medium-grained } \\
\text { metasandstone with sub-rounded to } \\
\text { rounded grains and cross-stratification }\end{array}$ \\
\hline SC-06B & $654219 / 7807213$ & $119(72)$ & $\begin{array}{l}\text { The base of Córrego do } \\
\text { Garimpo member (Antônio } \\
\text { dos Santos Formation) }\end{array}$ & $\begin{array}{l}\text { Matrix-supported metaconglomerate } \\
\text { with metasandstone, quartz and iron } \\
\text { formation banded clasts }\end{array}$ \\
\hline
\end{tabular}

${ }^{1}$ Samples analyzed by Dutra (2017). 
LSX-213 G2 + laser ablation system. Integration times were $15 \mathrm{~ms}$ for ${ }^{206} \mathrm{~Pb}$ and ${ }^{238} \mathrm{U}, 40 \mathrm{~ms}$ for ${ }^{207} \mathrm{~Pb}$, and $10 \mathrm{~ms}$ for ${ }^{208} \mathrm{~Pb}$, ${ }^{204} \mathrm{~Pb}+{ }^{204} \mathrm{Hg}$, and ${ }^{232} \mathrm{Th}$. The laser spot size was $20 \mu \mathrm{m}$ and the repetition rate, $10 \mathrm{~Hz}$. Helium was used as a carrier gas mixed with argon prior to introduction into the ICP-MS. Common Pb, instrumental mass discrimination and laser-induced elemental fractionation of $\mathrm{Pb} / \mathrm{U}$ were corrected by normalizing the $\mathrm{U} /$ $\mathrm{Pb}$ and $\mathrm{Pb} / \mathrm{Pb}$ ratios of the sample's zircons to zircon standards and $\mathrm{Pb}$ composition to the reference zircon GJ-1 (Jackson et al. 2004) of each analytical session (Stacey and Kramers 1975), using the Glitter software package (van Achterbergh et al.2001). Multiple analyses of the Plešovice reference zircon
(Sláma et al.2008) were performed during each session to test the validity of the method applied and the reproducibility of the age data obtained. The GJ-1 standard had weighted mean age of $605.3 \pm 0.9 \mathrm{Ma}(2 \sigma, \mathrm{n}=206, \mathrm{MSWD}=1.8)$ whereas the Plešovice secondary standard had a weighted mean age of $335.8 \pm 0.7 \mathrm{Ma}(2 \sigma, \mathrm{n}=113, \mathrm{MSWD}=1.7)$. The calculated ages agree, within uncertainty, with the accepted ID-TIMS ages reported for reference zircons by Jackson et al. (2004) and Sláma et al. (2008), respectively.

The signal data were initially reduced using the Glitter software package (van Achterbergh et al. 2001). An in-house Excel spreadsheet was used for taking all mass-bias and drifts

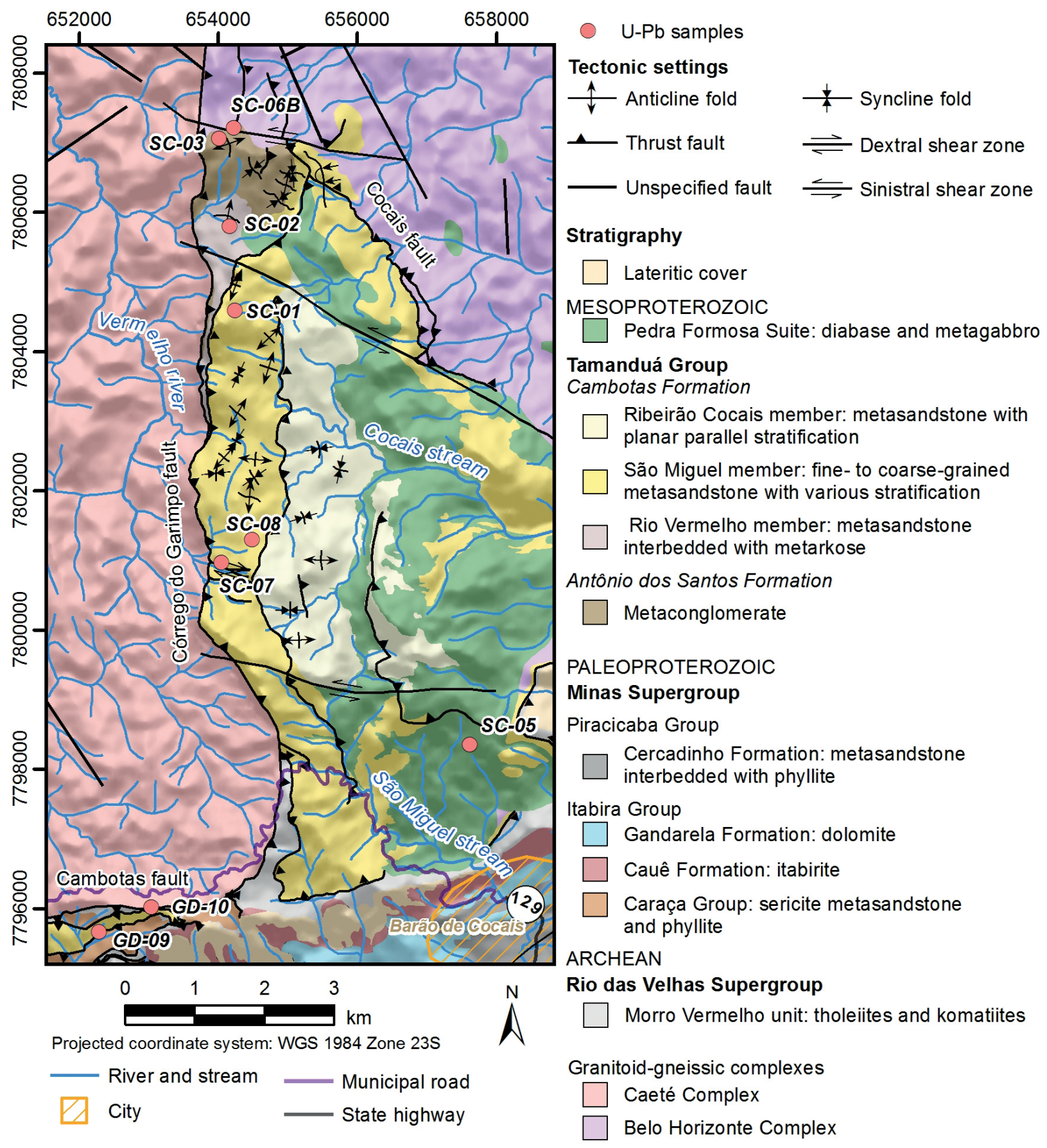

Figure 7. U-Pb geochronology samples of Tamanduá Group (based on Crocco-Rodrigues 1991, Brandalise and Heineck 1999, Saraiva 2012, Katahira 2013, Almeida-Filho et al.2015, Gomes 2017). Hydrography data from the Brazilian Institute of Geography and Statistics (IBGE 2017). 
corrected counts exported from Glitter into account. The age distributions, concordia diagrams, and weighted mean ages were plotted and calculated with Isoplot 4.15 (Ludwig 2009).

The results of the LA-ICP-MS analyses for samples and reference zircons are reported in the Supplementary Data. The maximum discordance considered was $5 \%$, and the diagrams are given by the ${ }^{207} \mathrm{~Pb} /{ }^{206} \mathrm{~Pb}$ ages and all errors are displayed as two standard deviations $(2 \sigma)$.

\section{U-Pb Results}

Zircon grains are mostly round and, in some cases, subhedral. The presence of fractures is frequent. The grains range from translucent to light brown and vary between 50 to $550 \mu \mathrm{m}$. CL images showed that most of the zircon grains have faint to complete absence zoning, with only a small number of grains exhibiting strong oscillatory zoning (Fig. 8).
The samples of Antônio dos Santos Formation have main peak age distribution (Fig. 9) between 2199-1962 Ma, followed by the Meso-Neoarchean population at 2590-2847 Ma. The sample SC-06B (Córrego do Garimpo member, Fig. 9H) shows the main population in the Rhyacian-Orosirian period (2248-1892 Ma, $\mathrm{n}=57$ ) followed by the Neoarchean one $(2757-2590 \mathrm{Ma}, \mathrm{n}=11)$. The youngest age is $1892 \pm 20 \mathrm{Ma}$ (99.9\% conc.), and the older one (3452 $\pm 18 \mathrm{Ma}, 97.9 \%$ conc.) predates the first Archean tectonomagmatic event, the Santa Bárbara event (ca. $3200 \mathrm{Ma}$ ). The sample SC-03 (Serra do Garimpo member, Fig. 9G) is like the previous one and shows its main peak in 2289-2032 Ma $(\mathrm{n}=76)$. This sample has the youngest population ages of the Antônio dos Santos Formation, $1788-1724 \mathrm{Ma}(\mathrm{n}=4)$.

The Cambotas Formation samples (SC-02 of Rio Vermelho member, and SC-01, SC-07, SC-08, GD-09, and GD-10 of São
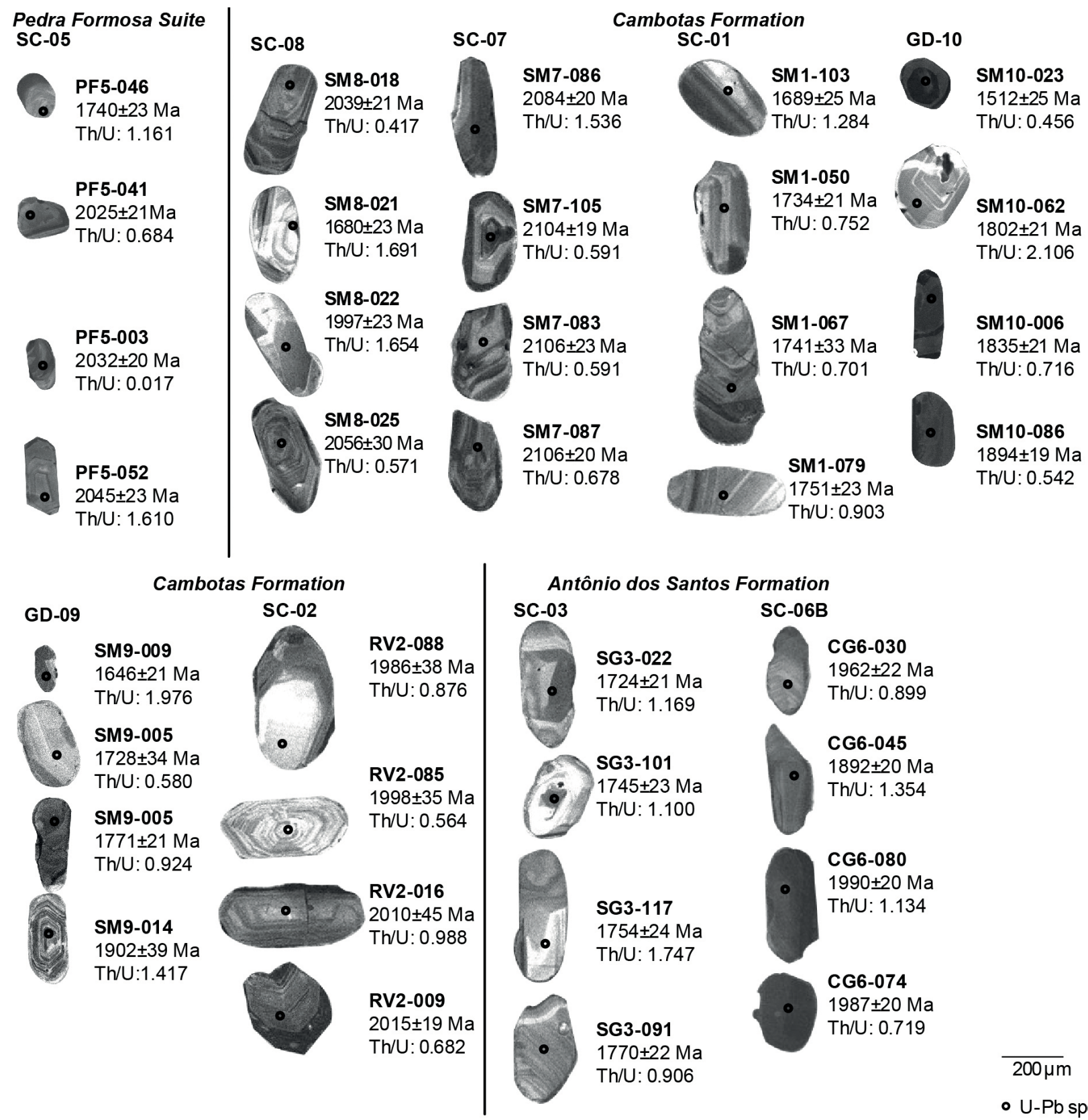

Figure 8. Cathodoluminescence images, ${ }^{207} \mathrm{~Pb} /{ }^{206} \mathrm{~Pb}$ ages and $\mathrm{Th} / \mathrm{U}$ ratio of some zircon grains from Tamanduá Group and Pedra Formosa Suite. 
Miguel member) record slightly different patterns from the base formation, mostly from Archean age (3109-2523 Ma, $\mathrm{n}=11$, Rio Vermelho member, Figure 9F), and having its main peak in the Rhyacian-Orosirian period (2300-1802 Ma, $\mathrm{n}=221$ ) (Fig. 9). The secondary population of sample SC-02 records ages from 2760 to $2513 \mathrm{Ma}(\mathrm{n}=10)$. The São Miguel member has the youngest and oldest ages of our database, $1512 \pm 25 \mathrm{Ma}$ (98.2\% conc., sample GD-10, Fig. 9E) and $3268 \pm 17 \mathrm{Ma}(98.9 \%$ conc., sample GD-09, Fig. 9D), respectively.

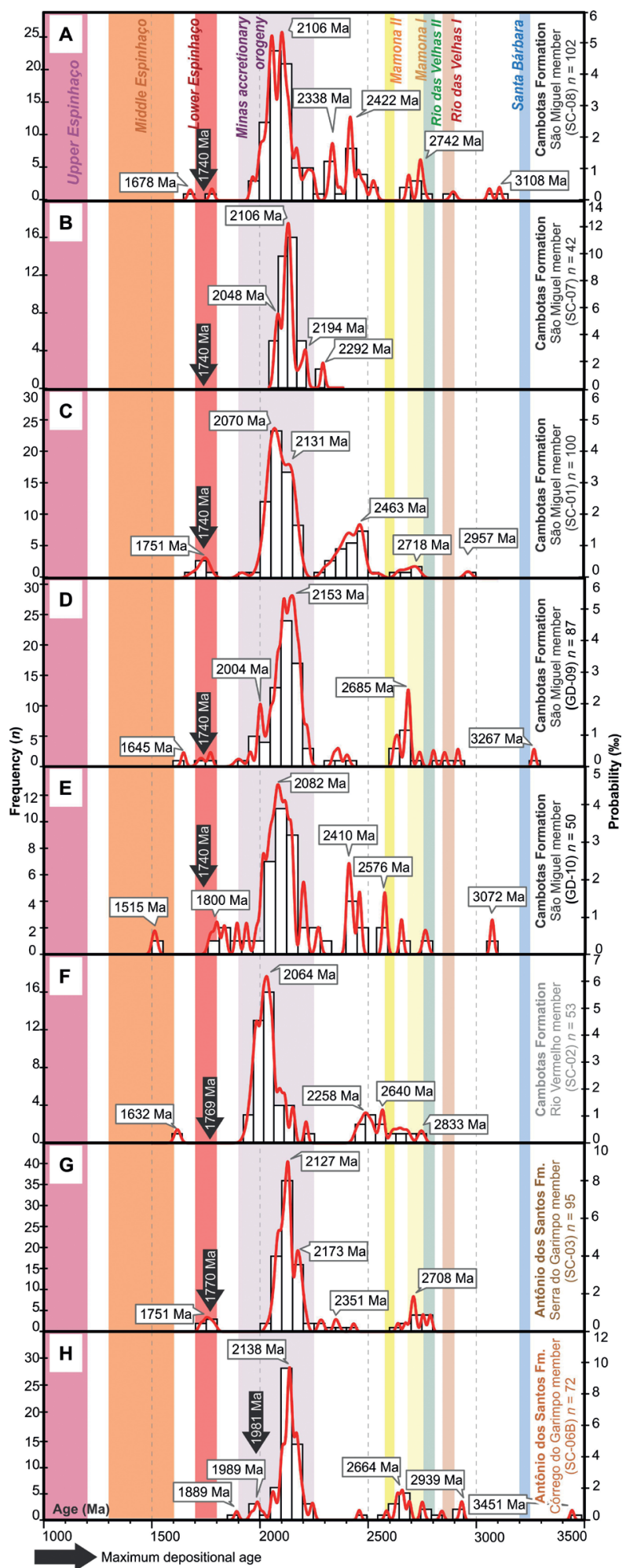

Figure 9. Histogram and maximum depositional age of Tamanduá Group samples.
The zircons of sample SC-05 (Pedra Formosa Suite) are mostly round and CL-dark; few grains are concentric oscillatory- and sector-zoned. Based on zoning patterns and $\mathrm{U}-(\mathrm{Th})-\mathrm{Pb}$ ages, the zircons are interpreted as inherited zircons (derived grain from melt sources) and zircon xenocrysts (zircon crystals incorporated from surrounding host rocks during the emplacement), as proposed by Miller et al. (2007). The youngest concordant zircon was dated at $1740 \pm 23 \mathrm{Ma}$ ( $100.1 \%$ conc.) and could indicate the minimum crystallization age of this mafic suite (Fig. 10).

\section{DISCUSSION}

\section{Maximum deposition and crystallization age}

The maximum deposition age is the most powerful application of detrital zircon geochronology, which contributes useful information for strata that are devoid of volcanic units and fossils (Gehrels 2014). However, some complexities can result in misleading measures as loss of radiogenic $\mathrm{Pb}, \mathrm{Th} / \mathrm{U}$ ratio, and the inadequate number of data. The best way to avoid misleading interpretations is to analyze samples from different levels of a stratigraphic section (Gehrels 2014) and the use of the youngest $2 \sigma$ grain cluster (YC2 $\sigma(3+))$. This methodology was developed by Dickinson and Gehrels (2009), and it provides that the maximum deposition age of a metasedimentary sample can be measured via weighted mean age or peak age probability of the youngest cluster $(n \geq 3)$. The youngest single grain (YSG) is compatible in $90 \%$ of the studied cases, but it could not pose statistical validity. Table 3 summarizes the application of this methodology on the database.

The age of the youngest grain cluster of each member proved to be more relevant than the individual measure of each sample from detail analyses of the Tamanduá Group maximum deposition age, due to a more significant amount of data that reduce analytical errors (Tab. 4).

In summary, the ages of ca. 1770 and $1740 \mathrm{Ma}$ are assumed as maximum depositional ages from the Antônio dos Santos and Cambotas formations, respectively. The age of the base

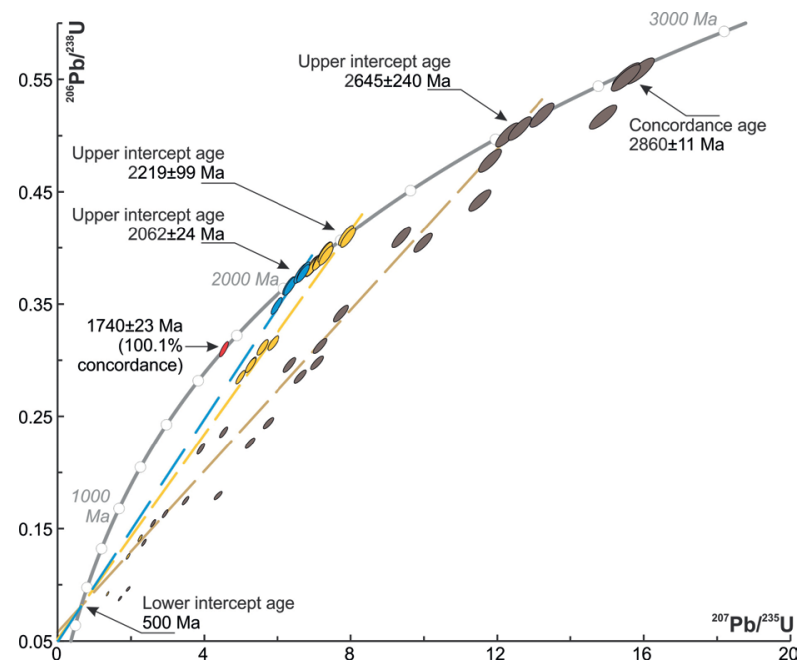

Figure 10. Concordia diagram for Pedra Formosa Suite. 
unit of Cambotas Formation, Rio Vermelho member, is measured by the ages of the secondary youngest grains cluster of São Miguel member; otherwise, its age was older than Antônio dos Santos Formation, due to the absence of grain cluster with $\mathrm{n} \geq 3$ younger than $1770 \mathrm{Ma}$. The maximum deposition age of Córrego do Garimpo member was stipulated by the weighted mean age of youngest grain cluster $(1981 \pm 36 \mathrm{Ma})$, but the youngest single grain could have geochronological validity considering that it is older than the age of the overlying unit, Serra do Garimpo member (1892 $\pm 20 \mathrm{Ma}, 99.9 \%$ conc.).

The single zircon of $1740 \pm 23 \mathrm{Ma}$ is interpreted as the minimum age of the Pedra Formosa Suite (Fig. 10), and it is like the magmatic pulse relative to the opening of Espinhaço basin (Silva et al. 1995). This data is inaccurate in determining the age of the Pedra Formosa magmatism, although it is compatible with the geological setting of the study area by presenting similar age to that of São Miguel member (1740 \pm 12 Ma, Tab. 4), which can be an inherited zircon from this unit. The Th/U rate does not suggest a metamorphic origin to those grains, due to the rate, being more than 0.1 .

\section{Provenance and implications for the evolution of the Tamanduá Group}

The histograms of detrital zircon ages of metasedimentary rocks of Tamanduá Group (Fig. 9) have age distributions with main peaks related to the Minas accretionary orogeny $(n=471)$, followed by populations from Meso- to Neoarchean periods ( $\mathrm{n}=13$, non-specific tectonomagmatic event), Mamona I $(\mathrm{n}=13)$ and Santa Bárbara events $(\mathrm{n}=4)$. Zircon ages allied with the collisional stage of Minas accretionary orogeny (2250-2080 Ma; Endo and Machado 2002, Aguilar et al. 2017) correspond to $67 \%$ of its age population $(n=316)$, with the remainder $(\mathrm{n}=155)$ being related with the post-collisional magmatism (> $2080 \mathrm{Ma}$, Aguilar et al. 2017). The RhyacianSiderian sources were probably plutons of the Mineiro Belt in the southeast of the QF as Alto Maranhão (2130 $\pm 2 \mathrm{Ma}$, Noce 1995, 2128 $\pm 10 \mathrm{Ma}$, Seixas et al.2013), Ritápolis (2123 $\pm 33 \mathrm{Ma}$, Teixeira et al. 2014), Rio Grande (2095 $\pm 12 \mathrm{Ma}$, Barbosa et al. 2015), Serrinha-Tiradentes (from $2227 \pm 22$ to $2204 \pm 11 \mathrm{Ma}$, Ávila et al. 2010, 2014), Lagoa Dourada (2350 \pm 4 and $2356 \pm 3 \mathrm{Ma}$, Seixas et al. 2012; $2351 \pm 48$ and $2317 \pm 16 \mathrm{Ma}$, Teixeira et al. 2015), Cassiterita (from 2472 \pm 11 to $2414 \pm 29 \mathrm{Ma}$, Barbosa 2015), and associated units.

The post-Orosirian ages families $(\mathrm{n}=25)$ are the youngest ones and represent two sedimentar cycles (Middle- and Lower Espinhaço) of the Espinhaço System. These zircon ages are related with the intrusive rocks, whose crystallization age ranges from 1724 to $1501 \mathrm{Ma}$ (see Fig. 4 of Guadagnin and Chemale Jr. 2015), as Borrachudos Suite (Dussin and Dussin 1995), K-alkaline (hematite-phyllite) intrusions in the São

Table 3. U-Pb detrital zircon ages of Tamanduá Group in this study.

\begin{tabular}{|c|c|c|c|c|}
\hline \multirow{2}{*}{ Unit } & \multirow{2}{*}{ Samples } & \multirow{2}{*}{$\begin{array}{l}\text { Youngest single grain } \\
\text { (concordance) }\end{array}$} & \multicolumn{2}{|c|}{ Youngest grain cluster with $n \geq 3$} \\
\hline & & & Peak age probability & Weighted mean age (MSWD) \\
\hline \multirow{5}{*}{ São Miguel member ${ }^{\mathrm{CF}}$} & SC-08 & $1680 \pm 23 \mathrm{Ma}(100.1 \%)$ & $1967 \mathrm{Ma}$ & $1976 \pm 42 \mathrm{Ma}(2.4)$ \\
\hline & SC-07 & $2030 \pm 24 \mathrm{Ma}(104.3 \%)$ & $2048 \mathrm{Ma}$ & $2039 \pm 9 \mathrm{Ma}(0.56)$ \\
\hline & SC-01 & $1689 \pm 25 \mathrm{Ma}(98.8 \%)$ & $1751 \mathrm{Ma}$ & $1742 \pm 13 \mathrm{Ma}(0.58)$ \\
\hline & GD-09' & $1646 \pm 21 \mathrm{Ma}(101.7 \%)$ & $2004 \mathrm{Ma}$ & $1999 \pm 10 \mathrm{Ma}(0.03)$ \\
\hline & GD-10 $10^{1}$ & $1512 \pm 25 \mathrm{Ma}(98.2 \%)$ & $2017 \mathrm{Ma}$ & $2028 \pm 15 \mathrm{Ma}(2.7)$ \\
\hline Rio Vermelho member ${ }^{\mathrm{CF}}$ & $\mathrm{SC}-02$ & $1626 \pm 30 \mathrm{Ma}(103.9 \%)$ & - & $1988 \pm 22 \mathrm{Ma}(0.38)$ \\
\hline Serra do Garimpo member ${ }^{\mathrm{AF}}$ & SC-03 & $1724 \pm 21 \mathrm{Ma}(100.0 \%)$ & $1751 \mathrm{Ma}$ & $1770 \pm 41 \mathrm{Ma}(2.0)$ \\
\hline Córrego do Garimpo member ${ }^{\mathrm{AF}}$ & SC-06B & $1892 \pm 20 \mathrm{Ma}(99.9 \%)$ & $1989 \mathrm{Ma}$ & $1981 \pm 36 \mathrm{Ma}(2.0)$ \\
\hline
\end{tabular}

${ }^{1}$ Samples analyzed by Dutra (2017), ${ }^{\mathrm{CF}}$ Cambotas Formation; ${ }^{\mathrm{AF}}$ Antônio dos Santos Formation.

Table 4. Maximum depositional age of Tamanduá Group units.

\begin{tabular}{|c|c|c|c|c|c|}
\hline \multirow[b]{2}{*}{ Unit } & \multirow[b]{2}{*}{ Samples } & \multirow{2}{*}{$\begin{array}{c}\text { Youngest } \\
\text { single grain } \\
\text { (concordance) }\end{array}$} & \multicolumn{2}{|c|}{ Youngest grain cluster with $\mathbf{n} \geq 3$} & \multirow{2}{*}{$\begin{array}{c}\text { Maximum } \\
\text { deposition age }\end{array}$} \\
\hline & & & $\begin{array}{c}\text { Peak age } \\
\text { probability }\end{array}$ & $\begin{array}{l}\text { Weighted mean age } \\
\text { (MSWD) }\end{array}$ & \\
\hline São Miguel member ${ }^{\mathrm{CF}}$ & $\begin{array}{l}\text { SC-08, SC-07, SC-01, } \\
\text { GD-09 }{ }^{1} \text { and GD- } 10^{1}\end{array}$ & $\begin{array}{l}1512 \pm 25 \mathrm{Ma} \\
(98.2 \%)\end{array}$ & $1744 \mathrm{Ma}$ & $1740 \pm 12 \mathrm{Ma}(0.58)$ & $1740 \pm 12 \mathrm{Ma}$ \\
\hline Rio Vermelho member ${ }^{\mathrm{CF}}$ & SC-02 & $\begin{array}{c}1626 \pm 30 \mathrm{Ma} \\
(103.9 \%)\end{array}$ & $1776 \mathrm{Ma}^{2}$ & $1769 \pm 11 \mathrm{Ma}(1.2)^{2}$ & $1769 \pm 11 \mathrm{Ma}^{2}$ \\
\hline Serra do Garimpo member ${ }^{\mathrm{AF}}$ & SC-03 & $\begin{array}{l}1724 \pm 21 \mathrm{Ma} \\
(100 \%)\end{array}$ & $1751 \mathrm{Ma}$ & $1770 \pm 41 \mathrm{Ma}(2.0)$ & $1770 \pm 41 \mathrm{Ma}$ \\
\hline Córrego do Garimpo member ${ }^{\mathrm{AF}}$ & SC-06B & $\begin{array}{l}1892 \pm 20 \mathrm{Ma} \\
(99.9 \%)\end{array}$ & $1989 \mathrm{Ma}$ & $1981 \pm 36 \mathrm{Ma}(2.0)$ & $1981 \pm 36 \mathrm{Ma}$ \\
\hline
\end{tabular}

${ }^{1}$ Samples analyzed by Dutra (2017); ${ }^{2}$ age of second youngest grains cluster of São Miguel member samples; ${ }^{\mathrm{CF} C a m b o t a s ~ F o r m a t i o n ; ~}{ }^{\mathrm{AF}}$ Antônio dos Santos Formation. 
João da Chapada Formation (Dussin 1994, Chemale Jr. et al. 2012), Conceição do Mato Dentro rhyolite (Brito Neves et al. 1979, Abreu 1991), and Mato Verde Group (Costa et al. 2014, 2018) in the Southern Espinhaço.

The limited contribution of Archean crustal in the Tamanduá basin can be attributed to the continuous process of peneplanation of this terrain and the sediments derived from distant source areas such as Southern Espinhaço.

The Tamanduá basin can be characterized as a long-lived basin in the Statherian period and its stratigraphy evolution is related to two stages of basin filling. The first one is associated with Antônio dos Santos Formation, an early intracontinental rifting sedimentation that was succeeded by a flexural stage, characterized by the rapid deposition (ca. $1.1 \mathrm{~km}$ in a maximum period of $30 \mathrm{Myr}$ ) of Cambotas Formation (Fig. 11).

The Antônio dos Santos Formation is related to tectonically-driven continental sedimentation under dry conditions. The immaturity of quartz-feldspathic clasts (pebbles and cobbles) of Córrego do Garimpo member's metaconglomerate indicates that the sediments were derived from proximal highlands dominated by granitic-like and supracrustal rocks of QF, indicated by a higher contente of banded iron-formation pebbles and cobbles. This sedimentary contribution is recorded by 2500-2000 Ma population in the histogram
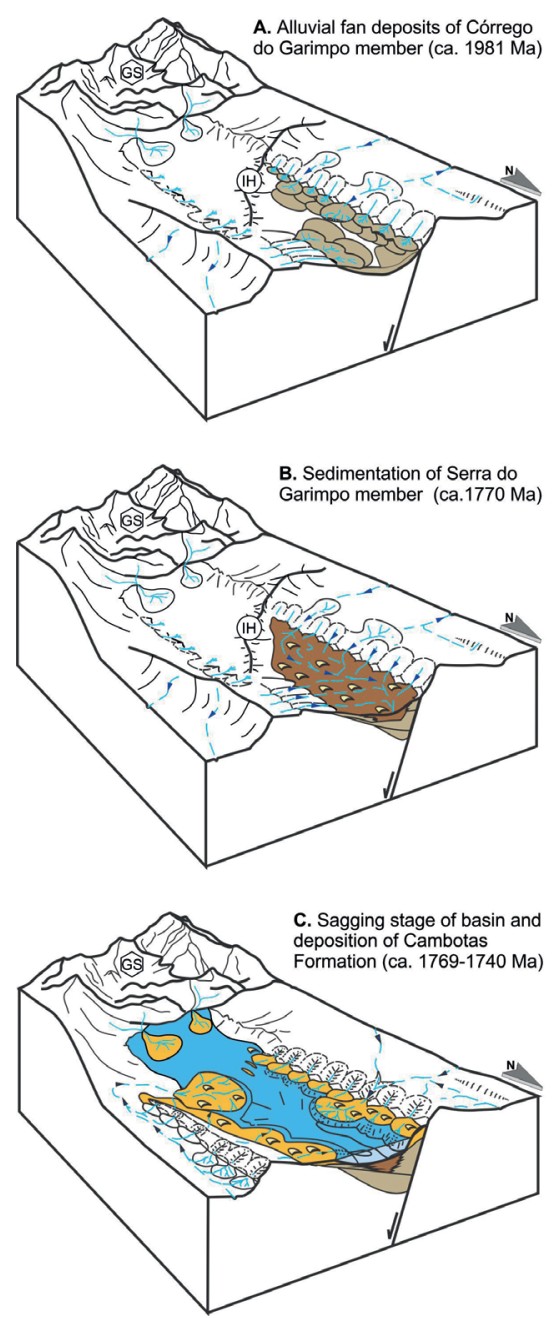

IH) Intrabasin high

GS Gandarela syncline Intermittent river

Cambotas Formation coastal with eolian marine sediments

Antônio dos Santos Formation

Serra do Garimpo member: aeolian deposit $(\neg)$ or playa Córrego do Garimpo

Archean granite-gneiss and supracrustal rocks (Rio das Velhas and Minas supergroups)

Source: based on Figures from Gawthorpe and Leeder (2000).

Figure 11. Tectono-sedimentary evolution of Tamanduá Group.
(Fig. 9). The metaconglomerate exhibits a coarsening-upward succession, and the metasandstone in the base of Córrego do Garimpo member shows lens-form with core coarser than borders. Those architectural elements indicate this sedimentation was in an aluvial fan environment, located near the rift border fault. It can be inferred because of the significant deformation of the metaconglomerate next to the contact with the granite-gneiss complex, which indicates adjacent highlands to deposits during the basin inversion process. The abundance of granitic pebbles and cobbles suggests a tectonically active setting in an arid to semi-arid climate, where the well-rounded grains of quartz support eolian abrasion of loose detritus on stable landforms (Patranabis-Deb and Kumar Chaudhuri 2007). The permanence of arid to semi-arid climate propitiated the aeolian deposition of Serra do Garimpo member at ca. 1770 $\pm 41 \mathrm{Ma}$, and despite its restricted occurrence, this member could record the tectonic quiescence of the Tamanduá basin (Fig. 11). The geochronological data of Antônio dos Santos Formation possibly indicates a paraconformity between the Serra do Garimpo and Córrego do Garimpo members which probably corresponds to a hiatus of ca. $240 \mathrm{Myr}$. The controlled expression of the Antônio dos Santos Formation may suggest a segmentation of the basin due to transfer fault. This structure is oblique to the rift border fault and uplifts as intrabasin high (IH) (Figs. 11A and 11B).

The increase of basin subsidence led to marine incursion and changes in depositional style and source areas. We interpret the variations in Mesoproterozoic age from the base to the upper part of the Tamanduá Group as a rejuvenation effect of the base and middle portions of the Cambotas Formation (samples GD-10 and SC-08, respectively). The sagging stage of Tamanduá basin, represented by the Cambotas Formation, unconformably overlies the Antonio dos Santos Formation.

The nature of the erosional contact between the top unit of Antônio dos Santos Formation (Serra do Garimpo member) and the basal one of Cambotas Formation (Rio Vermelho member) is abrupt, due to its very similar maximum depositional ages and the change of depositional style followed by a concomitant change of sources. The Rio Vermelho member records the coastal deposits marked by a significant contribution of Orosirian-Statherian source areas (Fig. 9), whose feldspar grain preservation indicates the permanence of arid to semiarid climate. The São Miguel member registers the transition of coastal to marine sediments; this sedimentation could be influenced by eolian contributions as suggested by grain size predomination and sedimentary stratifications. The upper unit, Ribeirão Cocais member, points to the rise of sea level over clastic rocks of base units of Tamanduá basin (Fig. 11).

Our stratigraphic framework and the $\mathrm{U}-\mathrm{Pb}$ age patterns ally the Tamanduá Group to the Mesoproterozoic Espinhaço rift-sag system (Chemale Jr. et al. 2012, Guadagnin and Chemale Jr. 2015).

Based on our geochronological data, the maximum depositional age of Serra do Garimpo member (Antônio dos Santos Formation, $1770 \pm 41 \mathrm{Ma}$ ) suggests a chrono-correlation with the early sedimentation units of Statherian rifts (Fig. 12). The maximum deposition age of Serra do Garimpo member indicates 
equivalence with the Statherian rhyolite ( $1771 \pm 2 \mathrm{Ma}$ ) associated with initial syn-rift sedimentation (alluvial fan, braided river, eolian, and lacustrine deposits; Alvarenga et al.2000) of the Araí Group (Pimentel et al. 1991) and the granitic plutons of Rio Paranã Suite, which shows crystallization age of Soledade and Sucuri granite of $1769 \pm 2$ and $1767 \pm 10 \mathrm{Ma}$ (Pimentel et al. 1991), respectively. Furthermore, the volcano-sedimentary successions of Algodão rifting (Northern Espinhaço) record similar ages, $1775 \pm 7 \mathrm{Ma}$ (Danderfer Filho et al.2015).

The maximum depositional ages proposed from São Miguel member (Cambotas Formation) indicates a correlation with Bandeirinha Formation in the Southern Espinhaço, Rio dos Remédios Group in the Chapada Diamantina, and Sapiranga Synthem in the Northern Espinhaço. The Bandeirinha Formation represents the alluvial fan conglomerates, braided river, and eolian deposits from the rift basin deposited in 1737 $\pm 11 \mathrm{Ma}$ (Chemale Jr. et al. 2012, Santos et al. 2013). The Rio dos Remédios Group encompasses acid lavas and lacustrine to alluvial sediments, this magmatism is dated $1752 \pm 4$ (Schobbenhaus et al. 1994) and $1748 \pm 4 \mathrm{Ma}$ (Babinski et al. 1999), and it is coeval with Lagoa Real granitic-gneiss complex, whose emplacement ages range from $1750-1710 \mathrm{Ma}$
(Turpin et al. 1988, Lobato et al. 2015). The Sapiranga Synthem is characterized by a conglomerate with voluminous clasts of volcanic rocks, sandstone, and crystalline rocks and showed age of $1740 \pm 11 \mathrm{Ma}$ (Danderfer et al. 2009).

If considering just the youngest zircon grains, the Tamanduá Group sedimentation could range from Lower $(1.80-1.68 \mathrm{Ga})$ to Middle Espinhaço (1.60-1.38 Ga) events (Fig. 12). The Antônio dos Santos Formation (1724 $\pm 21 \mathrm{Ma}, 100.0 \%$ conc.) would be chrono-correlated with continental sediments of the Lower Espinhaço event, while the sedimentation of Cambotas Formation would be focused solely in the Middle Espinhaço event at $1512 \pm 25 \mathrm{Ma}$ (98.2\% conc.) and chrono-correlated with the Veredas (Northern Espinhaço, maximum depositional age at ca. 1500 Ma; Franz et al. 2014) and Tiradentes Formations (Southern Brasília Belt, 1514 14 Ma, Ribeiro et al. 2013).

The stratigraphic stacking of the Tamanduá Group seems to be correlated to Stenian-Tonian units of the Southern Espinhaço Supergroup. However, there are no key units to make it clear. As proposed by Gomes (2017), the Antônio dos Santos Formation show lithological similarities with Galho do Miguel and Sopa-Brumadinho formations, whereas the Cambotas Formation with the Conselheiro Mata Group.

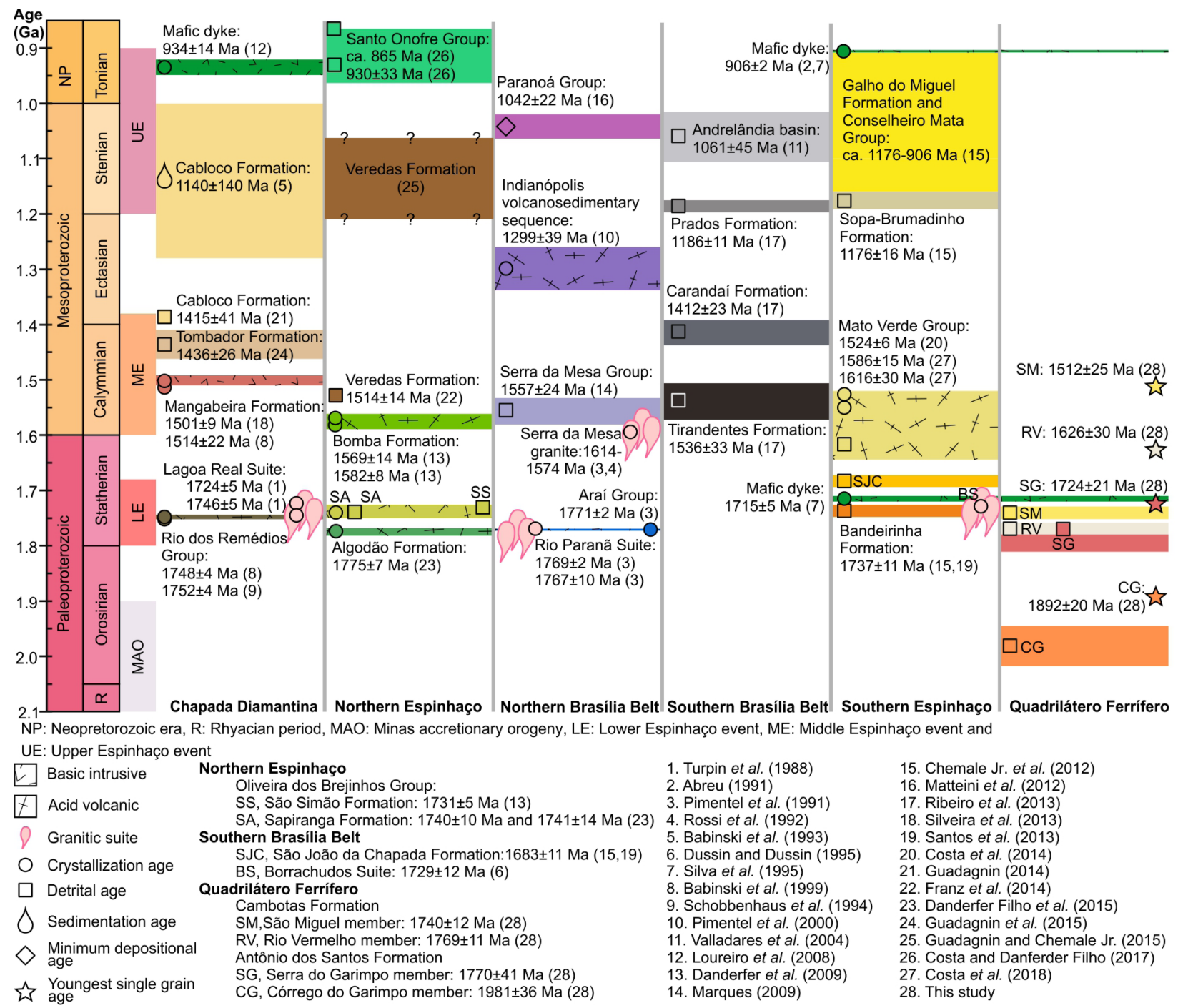

Source: based on Figures from Guadagnin and Chemale Jr. (2015).

Figure 12. Temporal relations of lithostratigraphic units of the Espinhaço system. 
In this scenario, the Antônio dos Santos Formation would represent a local segment of the Stenian rift systems that took place in the eastern border of SFC, limited to the north by the Caeté Complex, and to the south by the Gandarela syncline, both acting at the same time as structural highs and local sediment sources.

The Cambotas Formation would correspond to a short section of the marine deposits of the Conselheiro Mata Group, recording an intracratonic sag basin as described by Lopes (2012) and Santos et al. (2015). The provenance is related to the recycling of ancient sources, typical of a craton interior sag basin, and, secondarily, the input of younger sources, most likely from the underlying rift basin (Santos et al. 2015).

We emphasize that the maximum depositional ages proposed here do not exclude this possible chrono-correlation, but the geochronological database does not statistically support it.

\section{CONCLUSIONS}

Based on our field and $\mathrm{U}-\mathrm{Pb}$ data, the following conclusions are emphasized:

- The Tamanduá basin can be characterized as a long-lived basin related to two stages of basin filling. The first one is associated with Antônio dos Santos Formation, an early intracontinental rifting sedimentation succeeded by a flexural stage, characterized by the rapid deposition of the Cambotas Formation;

- The Antônio dos Santos Formation is related to tectonically-driven continental sedimentation under dry conditions. The Córrego do Garimpo Member, on the bottom, indicates that the sedimentation was in an alluvial fan environment close to rift border faults, composed by granitic-like rocks and supracrustal rocks of QF. The permanence of arid to semi-arid climate propitiated the eolian deposition of Serra do Garimpo member on top, recording the tectonic quiescence of Tamanduá basin and its segmentation due to transfer faults oblique to NS rift axis;

- The geochronological data of Antônio dos Santos Formation is dominated by Rhyacian-Siderian sources, corroborating the hypothesis of QF acting as a structural high, at the south, during its deposition. The data also indicate a possible paraconformity between the Serra do Garimpo and Córrego do Garimpo members (ca. $240 \mathrm{Myr}$ );

- The U-Pb detrital zircon pattern of the Tamanduá Group presents sources from the Paleoarchean to the Calymmian period. The proposed maximum age deposition for the Tamanduá Group is ca. 1740 Ma;

- The sag stage of Tamanduá basin is represented by the Cambotas Formation, overlying by unconformity the Antônio dos Santos Formation. The Rio Vermelho member records the initial subsidence of the basin and the beginning of the marine incursion. In contrast, São Miguel and Ribeirão Cocais members point to the rise of sea level over Antônio dos Santos Formation. The deposition of this formation records the recycling of older sources due to uplift, exposure, weathering, erosion and sedimentary transport of Paleo- to Mesoproterozoic terranes;

- The Pedra Formosa Suite crosscuts the metasedimentary package of the Tamanduá Group and has to be younger than $1740 \mathrm{Ma}$;

- We reinforce in this work the stratigraphic positioning of the Tamanduá Group as part of the Paleo-Mesoproterozoic Espinhaço rift-sag system. Our data exclude it from the Paleo-Neoarchean Rio das Velhas and Neoarchean-Siderian Minas supergroups of the QF.

\section{ACKNOWLEDGMENTS}

We thank the Microanalysis Laboratory of the Universidade Federal de Ouro Preto, a member of the Microscopy and Microanalysis Network ofMinas Gerais State/Brazil/FAPEMIG, for the CL images. We thank Mayko Neves for the courtesy of the picture. We are grateful for the comments and guidance from the editor-in-chief Claudio Riccomini, associate editor Mônica Heilbron and three anonymous reviewers who helped to improve this paper significantly. This project was sponsored by FAPEMIG (CRAAPEQ 03793-16), CNPq (307353/2019-2). We also thank Coordenação de Aperfeiçoamento de Pessoal de Nível Superior (CAPES) for their partial financial assistance and support on research (Finance Code 001).

\section{ARTICLE INFORMATION}

Manuscript ID: 20190069. Received on: 07/30/2019. Approved on: 03/30/2020.

L. F. D. and S. P. D. wrote the first draft of the manuscript. L. F. D. corrected the article and prepared all the images and tables. M. M. aided in the article revision and provided suggestions. C. L. revised the article and contributed advisors regarding geochronology and assisted in data interpretation. S. D., A. B. and T. T. provided data on the study area stratigraphy.

Competing interests: The authors declare no competing interests.

\section{REFERENCES}

Abreu F.R. 1991. Estudo das mineralizações auriferas filonianas da região da cidade de Diamantina/MG. Dissertation. Universidade Estadual de Campinas, Campinas, $100 \mathrm{p}$.

Aguilar C., Alkmim F.F., Lana C. \& Farina F. 2017. Palaeoproterozoic assembly of the São Francisco craton, SE Brazil: New insights from U-Pb titanite and monazite dating. Precambrian Research, 289:95-115. https:// doi.org/10.1016/j.precamres.2016.12.001
Alkmim F.F. 1987. Modelo Deposicional para a sequência de metassedimentos da Serra de Ouro Branco, Quadrilátero Ferrífero, Minas Gerais. Boletim da Sociedade Brasileira de Geologia Núcleo MG, 6:47-68.

Alkmim F.F., Lana C., Duque T.R.F. 2014. Zircões detríticos do Grupo Itacolomi e o registro do soerguimento do cinturão Mineiro. In: Congresso Brasileiro de Geologia, 47., 2014, Salvador, Brasil. Anais..., p. 1802. CD-ROM. 
Alkmim F.F. \& Marshak S. 1998. Transamazonian Orogeny in the Southern São Francisco Craton Region, Minas Gerais, Brazil: evidence for Paleoproterozoic collision and collapse in the Quadrilátero Ferrífero. Precambrian Research, 90(1-2):29-58. https://doi.org/10.1016/ S0301-9268(98)00032-1

Alkmim F.F. \& Martins-Neto M.A. 2012. Proterozoic first-order sedimentary sequences of the São Francisco craton, eastern Brazil. Marine and Petroleum Geology, 33(1):127-139. https://doi.org/10.1016/j.marpetgeo.2011.08.011

Almeida D.E. 1977. O Craton do São Francisco. Revista Brasileira de Geociências, 7(4):349-364.

Almeida L.G., Castro P.T., Endo I., Fonseca M.A. 2005. O Grupo Sabará no Sinclinal Dom Bosco, Quadrilátero Ferrífero: Uma Revisão Estratigráfica. Revista Brasileira de Geociências, 35(2):177-186.

Almeida-Filho A.C. de, Spatini F.D., Neves M.E.A. 2015. Relatório de mapeamento geológico, escala 1:10.000 - porção meridional da serra das Cambotas. Universidade Federal de Ouro Preto, Ouro Preto, 64 p.

Alvarenga C.J.S., Botelho N.F., Dardenne M.A., Campos J.E.G., Martins F.A.L., Meneses P.R., Moura M. 2000. Magmatic and stratigraphic evolution of a Paleo/Mesoproterozoic syn-rift to post-rift basin: example of the Araí Basin, Brazil. In: International Geologic Congress, Rio de Janeiro. Anais...

Amaral G., Matos J.T. de, Almeida Filho R., Cunha R.P., Paradella W.R. 1976. Carta geológica ao milionésimo da folha de Belo Horizonte. In: Congresso Brasileiro de Geologia, 29., Ouro Preto. Anais..., p. 229-238.

Angeli G. 2016. Arcabouço estrutural e contribuição à estratigrafia do Grupo Maquiné, Quadrilátero Ferrífero - MG. Dissertation, Universidade Federal de Ouro Preto, Ouro Preto, 104 p.

Ávila C.A., Teixeira W., Bongiolo E.M., Dussin I.A., Vieira T.A.T. 2014. Rhyacian evolution of subvolcanic and metasedimentary rocks of the southern segment of the Mineiro belt, São Francisco Craton, Brazil. Precambrian Research, 243:221-251. https://doi.org/10.1016/j. precamres.2013.12.028

Ávila C.A., Teixeira W., Cordani U.G., Moura C.A.V., Pereira R.M. 2010. Rhyacian (2.23-2.20 Ga) juvenile accretion in the southern São Francisco craton, Brazil: Geochemical and isotopic evidence from the Serrinha magmatic suite, Mineiro belt. Journal of South American Earth Sciences, 29(2):464-482. https://doi.org/10.1016/j.jsames.2009.07.009

Babinski M., Pedreira A.J., Brito Neves B.B., Van Schmus W.R. 1999. Contribuição à geocronologia da Chapada Diamantina. In: Simpósio Nacional de Estudos Tectônicos, 7., Lençóis. Anais..., p. 118-120.

Babinski M., Van Schmus W.R., Chemale Junior F., Brito Neves B.B., Rocha A.J.D. 1993. Idade isocrônica $\mathrm{Pb} / \mathrm{Pb}$ em rochas carbonâticas da Formação Caboclo, em Morro do Chapéu. In: Simpósio sobre o Cráton do São Francisco Evolução Tectónica e Metalogenética, 2., Salvador. Anais..., Sociedade Brasileira de Geologia, p. 160-163.

Barbosa N.S. 2015. Evolução paleoproterozoica do Cinturão Mineiro: geocronologia $\mathrm{U}-\mathrm{Pb}$, isótopos de $\mathrm{Nd}-\mathrm{Hf}$-Sr e geoquímica de rochas plutônicas. $\mathrm{PhD}$ Thesis, Universidade de São Paulo, São Paulo, 229 p. https://doi. org/10.11606/T.44.2015.tde-24082015-150603

Barbosa N.S., Teixeira W., Ávila C.A., Montecinos P.M., Bongiolo E.M. 2015. 2.17-2.10 Ga plutonic episodes in the Mineiro belt, São Francisco Craton, Brazil: U-Pb ages, geochemical constraints and tectonics. Precambrian Research, 270:204-225. https://doi.org/10.1016/j.precamres.2015.09.010

Besang C., Eberle W.G., Lahner L., Lenz H., Mollat H., Muller P., Paulsen S. 1977. Radiometrische Altersbestimmungen an Gesteinen, aus Minas Gerais, und Espirito Santo/Brasilien. Geologisches Jahrbuch, 24:149-179.

Brandalise L.A., Heineck C.A. (eds.). 1999. Programa Levantamentos Geológicos Básicos do Brasil. Belo Horizonte, Folha SE.23-Z-C-IV, Estado de Minas Gerais. Escala 1:100.000. Brasília, CPRM - Serviço Geológico do Brasil, $104 \mathrm{p}$.

Brito Neves B.B., Kawashita K., Cordani V.G., Delhal J. 1979. A evolução geocronológica da Cordilheira do Espinhaço: dados novos e integração. Revista Brasileira de Geociências, 9(1):71-85.

Brito Neves B.B., Sá J.M., Nilson A.A., Botelho N. 1995. A tafrogênese estateriana nos blocos paleoproterozóicos da América do Sul e processos subsequentes. Geonomos, 3(2):1-21. https://doi.org/10.18285/geonomos. v3i2.205
Castro L.O. \& Pedrosa C.J. 1982. Interpretação do Supergrupo Minas e do Grupo Tamanduá. In: Congresso Brasileiro de Geologia, 32., 1982, Salvador. Anais..., p. 138-152.

Cederberg J., Söderlund U., Oliveira E., Ernst R., Pisarevsky S. 2016. U-Pb baddeleyite dating of the Proterozoic Pará de Minas dyke swarm in the São Francisco craton (Brazil) - implications for tectonic correlation with Siberia, Congo and the North China cratons. GFF, 138(1):219-240. https://doi.or $\mathrm{g} / 10.1080 / 11035897.2015 .1093543$

Chemale Jr. F., Dussin I.A., Alkmim F.F., Martins M.S., Queiroga G., Armstrong R., Santos M.N. 2012. Unravelling a Proterozoic basin history through detrital zircon geochronology: The case of the Espinhaço Supergroup, Minas Gerais, Brazil. Gondwana Research, 22(1):200-206. https://doi.org/10.1016/j.gr.2011.08.016

Companhia de Pesquisa de Recursos Minerais - Serviço Geológico do Brasil (CPRM). Geobank. Available at: <http://geobank.cprm.gov.br/>. Acessed on: Jan. 30, 2018.

Companhia de Pesquisa de Recursos Minerais - Serviço Geológico do Brasil (CPRM). 2003. Mapa geológico do estado de Minas Gerais, escala 1:1.000.000. Belo Horizonte. Available at: <http://rigeo.cprm.gov.br/xmlui/handle/ doc/5016/>. Acessed on: May 24, 2019.

Companhia de Pesquisa de Recursos Minerais - Serviço Geológico do Brasil (CPRM).2014. Mapa geológico do estado de Minas Gerais, escala 1:1.000.000. Belo Horizonte.

Costa A.F. \& Danderfer Filho A. 2017. Tectonics and sedimentation of the central sector of the Santo Onofre rift, north Minas Gerais, Brazil. Brazilian Journal of Geology, 47(3):491-519. https://doi. org/10.1590/2317-4889201720160128

Costa A.F. de O., Danderfer A., Lana C. 2014. O registro do vulcanismo calimiano no Espinhaço Central ( $\mathrm{MG}$ ): caracterização petrofaciológica, geoquímica e geocronologica. Geociências, 33(1):119-135.

Costa A.F. de O., Danderfer A., Lana C. 2018. Stratigraphic and geochronological characterization of the Mato Verde group, Central Espinhaço (Brazil): An Eocalymmian rifting record in the western domain of the Congo-São Francisco paleocontinent. Journal of South American Earth Sciences, 84:16-33. https://doi.org/10.1016/j.jsames.2018.03.005

Crocco-Rodrigues F.A. 1991. Sistemas de Cavalgamento e Geologia Estrutural da Serra das Cambotas, Quadrilátero Ferrífero (MG). Dissertation, Universidade de Brasília, Brasília, 163 p

Crocco-Rodrigues F.A., Costa A.F., Souza F.A.C. 1989. Sistemas de Cavalgamento do Nordeste do Quadrilátero Ferrífero - MG. In: Simpósio de Geologia, 5., 1989, Belo Horizonte. Anais..., p. 6-10. SBG, v. 10.

Cutts K., Lana C., Alkmim F., Farina F., Moreira H., Coelho V. 2019. Metamorphism and exhumation of basement gneiss domes in the Quadrilátero Ferrífero: Two stage dome-and-keel evolution? Geoscience Frontiers, 10(5):1765-1787. https://doi.org/10.1016/j.gsf.2019.02.009

Danderfer A., De Waele B., Pedreira A.J., Nalini H.A. 2009. New geochronological constraints on the geological evolution of Espinhaço basin within the São Francisco Craton-Brazil. Precambrian Research, 170(12):116-128. https://doi.org/10.1016/j.precamres.2009.01.002

Danderfer Filho A., Lana C.C., Nalini Júnior H.A., Costa A.F.O. 2015. Constraints on the Statherian evolution of the intraplate rifting in a PaleoMesoproterozoic paleocontinent: New stratigraphic and geochronology record from the eastern São Francisco craton. Gondwana Research, 28(2):668-688. https://doi.org/10.1016/j.gr.2014.06.012

de Castro M.P., Queiroga G., Martins M., Alkmim F., Pedrosa-Soares A., Dussin I., Souza M.E. 2019. An Early Tonian rifting event affecting the São Francisco-Congo paleocontinent recorded by the Lower Macaúbas Group Araçuaí Orogen, SE Brazil. Precambrian Research, 331:105351. https://doi. org/10.1016/j.precamres.2019.105351

Dickinson W.R. \& Gehrels G.E. 2009. Use of U-Pb ages of detrital zircons to infer maximum depositional ages of strata: A test against a Colorado Plateau Mesozoic database. Earth and Planetary Science Letters, 288(1-2):115-125. https://doi.org/10.1016/j.epsl.2009.09.013

Dorr II J.V.N. 1969. Physiographic, stratigraphic, and structural development of the Quadrilatero Ferrifero, Minas Gerais, Brazil. Geological Survey Professional Paper, 641-A:1-110. https://doi.org/10.3133/pp641A 
Dussin I.A. \& Dussin T.M. 1995. Supergrupo Espinhaço: Modelo de evolução geodinâmica. Geonomos, 3(1):19-26. https://doi.org/10.18285/ geonomos.v3i1.212

Dussin I.A. 1994. Evolution structurale de la region de ÍEspinhaço meridional, bordure sud-est du craton São Francisco, Brésil. $\mathrm{PhD}$ thesis. Université D’orléans, $200 \mathrm{p}$.

Dutra L.F. 2017. Caracterização geocronológica U-Th-Pb de zircões detríticos na porção nordeste do sinclinal Gandarela - implicações para evolução sedimentar e geotectônica do Quadrilátero Ferrífero. Dissertation, Universidade Federal de Ouro Preto, Ouro Preto, 100 p.

Dutra L.F., Martins M., Lana C. 2019. Sedimentary and U-Pb detrital zircons provenance of the Paleoproterozoic Piracicaba and Sabará groups, Quadrilátero Ferrífero, Southern São Francisco craton, Brazil. Brazilian Journal of Geology, 49(2):e20180095. https://doi. org/10.1590/2317-4889201920180095

Endo I. \& Machado R. 2002. Reavaliação e novos dados geocronológicos $(\mathrm{Pb} / \mathrm{Pb}$ e K/Ar) da região do Quadrilátero Ferrífero e adjacências. Geologia USP Série Científica, 2:23-40. https://doi.org/10.5327/ S1519-874X2002000100005

Farina F., Albert C., Dopico C.M., Gil C.A., Moreira H., Hippertt J.P., Cutts K., Alkmim F.F., Lara C. 2016. The Archean-Paleoproterozoic evolution of the Quadrilátero Ferrífero (Brasil): Current models and open questions. Journal of South American Earth Sciences, 68:4-21. https://doi. org/10.1016/j.jsames.2015.10.015

Franz G., Morteani G., Gerdes A., Rhede D. 2014. Ages of protolith and Neoproterozoic metamorphism of Al-P-bearing quartzites of the Veredas formation (Northern Espinhaço, Brazil): LA-ICP-MS age determinations on relict and recrystallized zircon and geodynamic consequences. Precambrian Research, 250:6-26. https://doi.org/10.1016/j. precamres.2014.05.01

Freitas M.E., Crocco-Rodrigues F.A., Rosière C.A. 1991. Correlação do Quartzito Cambotas com a Seqüência Espinhaço apoiada por mapeamento geológico na escala 1:10.000. In: Simpósio de Geologia de Minas Gerais, 6., 1991 e Semana de Estudos de Ouro Preto, 30., 1991. Revista da Escola de Minas, 45(1/2):51-53.

Gawthorpe R.L. \& Leeder M.R. 2000. Tectono-sedimentary evolution of active extensional basins. Basin Research, 12(3-4):195-218. https://doi. org/10.1111/j.1365-2117.2000.00121.x

Gehrels G. 2014. Detrital zircon U-Pb geochronology applied to tectonics. Annual Review of Earth and Planetary Sciences, 42:127-149. https://doi. org/10.1146/annurev-earth-050212-124012

Gomes A.C.B. 2017. Arcabouço estratigráfico e estrutural do Grupo Tamanduá na serra das Cambotas, municípios de Barão de Cocais e Caeté, MG. Monograph, Universidade Federal de Ouro Preto, Ouro Preto, 55 p.

Guadagnin F. 2014. Arcabouço cronológico e proveniência do supergrupo espinhaço na região da Chapada Diamantina e bacias correlatas. $\mathrm{PhD}$ thesis, Universidade Federal do Rio Grande do Sul, Porto Alegre, 144 p.

Guadagnin F. \& Chemale Jr. F. 2015. Detrital zircon record of the Paleoproterozoic to Mesoproterozoic cratonic basins in the São Francisco Craton. Journal of South American Earth Sciences, 60:104-116. https://doi. org/10.1016/j.jsames.2015.02.007

Guadagnin F., Chemale Jr. F., Magalhães A.J.C., Santana A., Dussin I., Takehara L. 2015. Age constraints on crystal-tuff from the Espinhaço Supergroup - Insight into the Paleoproterozoic to Mesoproterozoic intracratonic basin cycles of the Congo-São Francisco Craton. Gondwana Research, 27(1):363-376. https://doi.org/10.1016/j. gr.2013.10.009

Guimarães D. 1931. Contribuição à geologia do Estado de Minas Gerais, Brasil. Boletim do Serviço Geológico e Mineralógico do Brasil, 55:1-36.

Guimarães S.N.P., Ravat D., Hamza V.M. 2014. Combined use of the centroid and matched filtering spectral magnetic methods in determining thermomagnetic characteristics of the crust in the structural provinces of Central Brazil. Tectonophysics, 624-625:87-99. https://doi.org/10.1016/j. tecto.2014.01.025

Harder E.C. \& Chamberlin R.T. 1915. The geology of central Minas Geraes, Brazil. The Journal of Geology, 23(4):341-378. https://doi. org/10.1086/622244
Herz N. 1970. Gneissic and Igneous Rocks of the Quadrilátero Ferrífero, Minas Gerais, Brazil. U.S. Geology Survey Professional Paper, 641-B:1-58. https://doi.org/10.3133/pp641B

Herz N. 1978. Metamorphic rocks of the Quadrilatero Ferrifero, Minas Gerais, Brazil. U.S. Geology Survey Professional Paper, 641-C:1-81. https:// doi.org/10.3133/pp641C

Hirson J. da R. 1967. Contribuição para o estudo do grupo Tamanduá da série Rio das Velhas (Minas Gerais, Brasil). PhD thesis, Universidade de Lisboa, Lisboa, 123 p.

Instituto Brasileiro de Geografia e Estatística (IBGE). 2017. Base cartográfica BC250. Available at: <https://www.ibge.gov.br/geociencias/ downloads-geociencias.html>. Accessed on: Jun. 15, 2019.

Jackson S.E., Pearson N.J., Griffin W.L., Belousova E.A. 2004. The application of laser ablation-inductively coupled plasma-mass spectrometry to in situ U-Pb zircon geochronology. Chemical Geology, 211 (1-2):47-69. https://doi.org/10.1016/j.chemgeo.2004.06.017

Katahira D.F. 2013. Mapeamento geológico em escala 1:25.000, na junção entre o Sinclinal do Gandarela e a Serra dos Cambotas, de Barão de Cocais - MG. Monograph, Universidade Federal de Minas Gerais, Belo Horizonte, 111 p.

Kleinspehn K.L. \& Paola C. (eds.). 1988. New Perspectives in Basin Analysis. New York, Springer. https://doi.org/10.1007/978-1-4612-3788-4

Ladeira E.A. 1982. Brief introduction to the geology of the Quadrilatero Ferrífero, Minas Gerais, Brazil. In: International Seminar on Lateritisation Process, 2., 1982. Anais..., p. 5-17.

Lana C., Alkmim F.F., Armstrong R., Scholz R., Romano R., Nalini Jr. H.A. 2013. The ancestry and magmatic evolution of Archaean TTG rocks of the Quadrilátero Ferrífero province, southeast Brazil. Precambrian Research, 231:157-173. https://doi.org/10.1016/j.precamres.2013.03.008

Lobato L.M., Baltazar O.F., Reis L.B., Achtschin A.B., Baars F.J., Timbó M.A., Berni G.V., Mendonça B.R.V., Ferreira D. 2005. Projeto Geologia do Quadrilátero Ferrífero - Integração e Correção Cartográfica em SIG com Nota Explicativa. Belo Horizonte, $68 \mathrm{p}$.

Lobato L.M., Pimentel M.M., Cruz S.C.P., Machado N., Noce C.M., Alkmim F.F. 2015. U-Pb geochronology of the Lagoa Real uranium district, Brazil: Implications for the age of the uranium mineralization. Journal of South American Earth Sciences, 58:129-140. https://doi.org/10.1016/j.jsames.2014.12.005

Lopes T.C. 2012. Contribuição ao estudo de proveniência sedimentar do Supergrupo Espinhaço na Serra do Cabral, MG. Dissertation, Universidade Federal de Minas Gerais, Belo Horizonte, 140 p.

Loureiro H.S.C., Lima E.S., Macedo E.R., Silveira F.V., Bahiense I.C., Arcanjo J.B.A., Moraes Filho J.C., Neves J.P., Guimares J.T., Teixeira L.R., Abram M.B., Santos R.A., Melo R.C., 2008. Mapa geológico do Projeto Barra e Oliveira Dos Brejinhos, escala 1:200.000. Brazilian Geological Survey and Bahia Mineral Research Company.

Ludwig K.R. 2009. User's Manual for Isoplot 3.70. Berkeley, Berkeley Geochronology Center Special Publication No. 4, 76 p.

Machado N. \& Abreu-Bentivi F.R. 1989. Preliminary U-Pb data on the evolution of the Proterozoic Espinhaco Orogen in Minas Gerais, Brazil. In: Joint Annual Meeting Geological Association of Canada Mineralogical Association of Canada, Canadian Geophysical Union, 1989. Program with abstracts..., 14:110.

Machado N., Schrank A., Noce C.M., Gauthier G. 1996. Ages of detrital zircon from Archean-Paleoproterozoic sequences: Implications for Greenstone Belt setting and evolution of a Transamazonian foreland basin in Quadrilátero Ferrífero, southeast Brazil. Earth and Planetary Science Letters, 141(1-4):259-276. https://doi.org/10.1016/0012-821X(96)00054-4

Marques G.C. 2009. Geologia dos grupos Araí e Serra da Mesa e seu embasamento no sul do Tocantins. Dissertation, Universidade de Brasília, Brasília, $116 \mathrm{p}$

Marshak S. \& Alkmim F.F. 1989. Proterozoic contraction/extension tectonics of the southern São Francisco Region, Minas Gerais, Brazil Tectonics, 8(3):555-571. https://doi.org/doi:10.1029/TC008i003p00555

Martínez Dopico C.I., Lana C., Moreira H.S., Cassino L.F., Alkmim F.F. 2017. U-Pb ages and Hf-isotope data of detrital zircons from the late Neoarchean-Paleoproterozoic Minas Basin, SE Brazil. Precambrian Research, 291:143-161. https://doi.org/10.1016/j.precamres.2017.01.026 
Matteini M., Dantas E.L., Pimentel M.M., de Alvarenga C.J.S., Dardenne M.A. 2012. $\mathrm{U}-\mathrm{Pb}$ and $\mathrm{Hf}$ isotope study on detrital zircons from the Paranoá Group, Brasília Belt Brazil: Constraints on depositional age at Mesoproterozoic - Neoproterozoic transition and tectono-magmatic events in the São Francisco craton. Precambrian Research, 206-207:168-181. https://doi.org/https://doi.org/10.1016/j.precamres.2012.03.007

Maxwell C.H. 1972. Geology and ore deposits of the Alegria District, Minas Gerais, Brazil. U.S. Geology Survey Professional Paper, 341-J:1-72. https:// doi.org/10.3133/pp341J

Miller J.S., Matzel J.E.P., Miller C.F., Burgess S.D., Miller R.B. 2007. Zircon growth and recycling during the assembly of large, composite arc plutons. Journal of Volcanology and Geothermal Research, 167(1-4):282-299. https:// doi.org/10.1016/j.jvolgeores.2007.04.019

Moore S.L. 1969. Geology and Ore Deposits of the Antônio dos Santos, Congo Sôco and Conceição do Rio Acima Quadrangles, Minas Gerais, Brazil. U.S. Geological Survey Professional Paper, 341-I:1-50.

Moreira H.S., Lana C., Nalini Jr. H.A. 2016. The detrital zircon record of an Archaean convergent basin in the Southern São Francisco Craton, Brazil. Precambrian Research, 275:84-99. https://doi.org/10.1016/j. precamres.2015.12.015

Noce C.M. 1995. Geocronologia dos eventos magmáticos, sedimentares e metamórficos na região do Quadrilátero Ferrífero, Minas Gerais. $\mathrm{PhD}$ thesis, Universidade de São Paulo, São Paulo, 128 p. https://doi. org/10.11606/T.44.2016.tde-05012016-154125

Nunes F.S. 2016. Contribuição à estratigrafia e geocronologia U-Pb de zircões detríticos da Formação Moeda (Grupo Caraça, Supergrupo Minas) na Serra do Caraça, Quadrilátero Ferrífero, Minas Gerais. Dissertation, Universidade Federal de Ouro Preto, Ouro Preto, 77p.

Patranabis-Deb S. \& Kumar Chaudhuri A. 2007. A retreating fan-delta system in the Neoproterozoic Chattisgarh rift basin, central India: Major controls on its evolution. AAPG Bulletin, 91(6):785-808. https://doi. org/10.1306/11270605182

Pimentel M.M., Fuck R.A., Jost H., Ferreira Filho C.F., Araújo S.M. 2000. The basement of the Brasília Fold Belt and the Goiás Magmatic Arc. In: Cordani U.G., Milani E.J., Thomaz Filho A., Campos D.A. (eds.). Tectonic Evolution of South America. Rio de Janeiro, p. 195-229.

Pimentel M.M., Heaman L., Fuck R.A., Marini O.J. 1991. U-Pb zircon geochronology of Precambrian tin-bearing continental-type acid magmatism in central Brazil. Precambrian Research, 52(3-4):321-335. https://doi.org/10.1016/0301-9268(91)90086-P

Reis L.A., Martins-Neto M.A., Gomes N.S., Endo I., Jordt-Evangelista H. 2002. A bacia de antepaís paleoproterozoica Sabará, Quadrilátero Ferrífero. Revista Brasileira de Geociências, 32(1):27-42

Ribeiro A., Teixeira W., Dussin I.A., Ávila C.A., Nascimento D. 2013. U$\mathrm{Pb}$ LA-ICP-MS detrital zircon ages of the São João del Rei and Carandaí basins: New evidence of intermittent Proterozoic rifting in the São Francisco paleocontinent. Gondwana Research, 24(2):713-726. https://doi. org/10.1016/j.gr.2012.12.016

Romano A.W., Rezende L.F.S, Macedo B.O.P. 2017. Folha Ouro Preto - SF.23-X-A-III, escala 1:100.000 - Mapa e nota explicativa. In: Projeto Triângulo Mineiro, Belo Horizonte, CODEMIG-UFMG-CPMTC, 68 p.

Romano R., Lana C., Alkmim F.F., Stevens G., Armstrong R. 2012. Stabilization of the southern portion of the São Francisco craton, SE Brazil, through a long-lived period of potassic magmatism. Precambrian Research, 224:143-159. https://doi.org/10.1016/j.precamres.2012.09.002

Rosière C.A., Bekker A., Rolim V.K., Santos J.O.S. 2019. Post-Great Oxidation Event Orosirian-Statherian iron formations on the São Francisco craton: Geotectonic implications. Island Arc, 28(4):e12300. https://doi. org/10.1111/iar.12300

Rossi P., Andrade G.F., Cocherie A. 1992. The 1.58 Ga A-type granite of Serra da Mesa (GO): an exemple of "NYF" fertile granite pegmatite. In: Congresso Brasileiro de Geologia, 37., 1992, São Paulo. Anais..., p. 389-390. Sociedade Brasileira de Geologia.

Santos J.O.S., Hartmann L.A., Faria M.S., Riker S.R., Miguel M., Almeida M.E., Mcnaughton N.J. 2006. A compartimentação do Cráton Amazonas em províncias: avanços ocorridos no período 2000-2006. In: Simpósio de Geologia da Amazônia, 9., 2006, Belém. Anais..., p. 156-159 Sociedade Brasileira de Geologia.
Santos M.N., Chemale Jr. F., Dussin I.A., Martins M., Assis T.A.R., Jelinek A.R., Guadagnin F., Armstrong R. 2013. Sedimentological and paleoenvironmental constraints of the Statherian and Stenian Espinhaço rift system, Brazil. Sedimentary Geology, 290:47-59. https://doi.org/10.1016/j. sedgeo.2013.03.002

Santos M.N., Chemale Jr. F., Dussin I.A., Martins M.S., Queiroga G.N., Pinto R., Santos A., Armstrong R. 2015. Provenance and paleogeographical reconstruction of a Mesoproterozoic intracratonic sag basin (Upper Espinhaço Basin, Brazil). Sedimentary Geology, 318:40-57. http://doi. org/10.1016/j.sedgeo.2014.12.006

Saraiva M.V.O. 2012. Mapeamento Geológico em Escala 1:10.000 na Região a oeste de Barão de Cocais - MG. Monography, Universidade Federal de Minas Gerais, Belo Horizonte, $110 \mathrm{p}$

Schobbenhaus C., Hoppe A., Baumann A., Lork A. 1994. U/Pb age of Rio dos Remedios volcanism, Chapada Diamantina, Bahia State, Brazil. In: Brazilian Congress on Geology, 38., 1994, Brazil. Anais ...

Schöll W.U. 1972. Der suedwestliche Randbereich der Espinhaço Zone, Minas Gerais, Brasilien. Geologisches Rundschan, 61:201-216. https://doi. org/10.1007/BF01836139

Schorscher H.D. 1978. Evolução geotectônica da parte meridional do Geossinclinal Espinhaço, Minas Gerais, Brasil. In: Congresso Brasileiro de Geologia, 30, Recife. Anais..., p. 44.

Schorscher H.D. 1979a. Evolução geotectônica e petrogenética do embasamento arqueano do Quadrilátero Ferrífero. Anais da Academia Brasileira de Ciências, 51(4):767-768.

Schorscher H.D. 1979b. Evolução arqueana e proterozoica do Quadrilátero Ferrífero e de partes meridionais da Serra do Espinhaço. In: Simpósio sobre o Cráton São Francisco e suas Faixas Marginais, Salvador. Anais..

Schorscher H.D. 1980. Contribuição à estratigrafia proterozoica do Quadrilátero Ferrífero. Anais da Academia Brasileira de Ciências, 52(1):52-195

Schorscher H.S. \& Guimarães P.F. 1976. Mina do Cauê. Estratigrafia e Tectônica do Supergrupo Minas e Geologia do Distrito Ferrífero de Itabira. In: Congresso Brasileiro de Geologia, 29., 1976, Ouro Preto. Roteiro das Excursões..., p. $75-86$.

Seixas L.A.R., Bardintzeff J.M., Stevenson R., Bonin B. 2013. Petrology of the high-Mg tonalities and dioritic enclaves of the ca. 2130Ma Alto Maranhão suite: Evidence for a major juvenile crustal addition event during the Rhyacian orogenesis, Mineiro Belt, southeast Brazil. Precambrian Research, 238:18-41. https://doi.org/10.1016/j.precamres.2013.09.015

Seixas L.A.R., David J., Stevenson R. 2012. Geochemistry, Nd isotopes and U-Pb geochronology of a 2350Ma TTG suite, Minas Gerais, Brazil: Implications for the crustal evolution of the Southern São Francisco craton. Precambrian Research, 196-197:61-80. https://doi.org/10.1016/j. precamres.2011.11.002

Silva A.M., Chemale Jr. F., Kumuyumjian R.M., Heaman L. 1995. Mafic dike swarms of Quadrilátero Ferrífero and Southern Espinhaço, Minas Gerais, Brazil. Revista Brasileira de Geociências, 25(2):124-137.

Silveira E.M., Söderlund U., Oliveira E.P., Ernst R.E., Leal A.B.M. 2013. First precise $\mathrm{U}-\mathrm{Pb}$ baddeleyite ages of $1500 \mathrm{Ma}$ mafic dykes from the São Francisco Craton, Brazil, and tectonic implications. Lithos, 174:144-156. https://doi.org/10.1016/j.lithos.2012.06.004

Simmons G.C. 1968. Geology and Mineral Resources of the Barão de Cocais Area, Minas Gerais, Brazil. U.S. Geology Survey Professional Paper, 341-H:1-46.

Simmons G.C. \& Maxwell C.H. 1961. Grupo Tamanduá da Série Rio das Velhas. DNPM, 211:1-31.

Sláma J., Košler J., Condon D.J., Crowley J.L., Gerdes A., Hanchar J.M., Horstwood M.S.A., Morris G.A., Nasdala L., Norberg N., Schaltegger U., Schoene B., Tubrett M.N., Whitehouse M.J. 2008. Plešovice zircon - A new natural reference material for $\mathrm{U}-\mathrm{Pb}$ and $\mathrm{Hf}$ isotopic microanalysis. Chemical Geology, 249(1-2):1-35. https://doi.org/10.1016/j.chemgeo.2007.11.005

Souza M.E., Martins M., Queiroga G.N., Leite M., Oliveira R.G., Dussin I., Pedrosa-Soares A.C. 2019. Paleoenvironment, sediment provenance and tectonic setting of Tonian basal deposits of the Macaúbas basin system, Araçuaí orogen, southeast Brazil. Journal of South American Earth Sciences, 96:102393, https://doi.org/10.1016/j.jsames.2019.102393 
Braz. J. Geol. (2020), 50(1): e20190069

Sperber M.V. 1977. Geologie des Praekambriums am Suedwestrand der Serra do Cipó (Serra do Espinhaço, Minas Gerais, Brasilien). Geologisches Jahrbuch, 24:93-148.

Stacey J.S. \& Kramers J.D. 1975. Approximation of terrestrial lead isotope evolution by a two-stage model. Earth and Planetary Science Letters, 26(2):207-221. https://doi.org/10.1016/0012-821X(75)90088-6

Teixeira W., Avila C.A., Bongiolo E.M., Hollanda M.H.B.M. de, Barbosa N. da S. 2014. Age and tectonic significance of the Ritápolis batholith, Mineiro belt (southern São Francisco Craton): U-Pb LA-ICP-MS, Nd isotopes and geochemical evidence. In: South American Symposium on Isotope Geology, 9., 2014. Anais... São Paulo, Instituto de Geociências - USP, p. 225.

Teixeira W., Ávila C.A., Dussin I.A., Corrêa Neto A. V., Bongiolo E.M., Santos J.O., Barbosa N.S. 2015. A juvenile accretion episode (2.35-2.32Ga) in the Mineiro belt and its role to the Minas accretionary orogeny: Zircon $\mathrm{U}-\mathrm{Pb}-\mathrm{Hf}$ and geochemical evidences. Precambrian Research, 256:148-169. https://doi.org/10.1016/j.precamres.2014.11.009

Teixeira W., Oliveira E.P., Marques L.S. 2017. Nature and Evolution of the Archean Crust of the São Francisco Craton. In: Heilbron M., Cordani
U.G., Alkmim F.F. (eds.). São Francisco Craton, Eastern Brazil: Tectonic Genealogy of a Miniature Continent. Cham, Springer International Publishing, p. 29-56. https://doi.org/10.1007/978-3-319-01715-0_3

Turpin L., Maruejol P., Cuney M. 1988. U-Pb, Rb-Sr and Sm-Nd chronology of granitic basement, hydrothermal albitites and uranium mineralization (Lagoa Real, South-Bahia, Brazil). Contributions to Mineralogy and Petrology, 98:139-147. https://doi.org/10.1007/BF00402107

U.S. Geological Survey. 2006. FGDC Digital Cartographic Standard for Geologic Map Symbolization (FGDC Document Number FGDCSTD-013-2006). iii-I78.

Valladares C.S., Machado N., Heilbron M., Gauthier G. 2004. Ages of detrital zircon from siliciclastic successions south of the São Francisco craton, Brazil: implications for the evolution of proterozoic basins. Gondwana Research, 7(4):913-921. https://doi.org/10.1016/S1342-937X(05)71074-1

van Achterbergh E., Ryan C.G., Jackson S.E., Griffin W. 2001. Data reduction software for LA-ICP-MS. In: Sylvester P. (ed.). Laser Ablation ICPMS in the Earth Science. Canada, Mineralogical Association of Canada, p. 239-243. 